NBER WORKING PAPER SERIES

\title{
ISSUER QUALITY AND THE CREDIT CYCLE
}

\author{
Robin Greenwood \\ Samuel G. Hanson \\ Working Paper 17197 \\ http://www.nber.org/papers/w17197
NATIONAL BUREAU OF ECONOMIC RESEARCH
1050 Massachusetts Avenue
Cambridge, MA 02138
July 2011

This paper was previously circulated under the title "Issuer Quality and Corporate Bond Returns." For helpful suggestions, we are grateful to Malcolm Baker, Effi Benmelech, Dan Bergstresser, John Campbell, Sergey Chernenko, Lauren Cohen, Ian Dew-Becker, Martin Fridson, Victoria Ivashina, Chris Malloy, Jun Pan, Erik Stafford, Luis Viceira, Jeff Wurgler, seminar participants at Columbia GSB, Dartmouth Tuck, Federal Reserve Bank of New York, Federal Reserve Board of Governors, Harvard Business School, MIT Sloan, NYU Stern, Ohio State Fisher, University of Chicago Booth, University of Pennsylvania Wharton, Washington University Olin, Yale SOM, and especially David Scharfstein, Andrei Shleifer, Jeremy Stein, and Adi Sunderam. We thank Annette Larson and Morningstar for data on bond returns and Mara Eyllon and William Lacy for research assistance. The Division of Research at the Harvard Business School provided funding. The views expressed herein are those of the authors and do not necessarily reflect the views of the National Bureau of Economic Research.

NBER working papers are circulated for discussion and comment purposes. They have not been peerreviewed or been subject to the review by the NBER Board of Directors that accompanies official NBER publications.

(C) 2011 by Robin Greenwood and Samuel G. Hanson. All rights reserved. Short sections of text, not to exceed two paragraphs, may be quoted without explicit permission provided that full credit, including (C) notice, is given to the source. 
Issuer Quality and the Credit Cycle

Robin Greenwood and Samuel G. Hanson

NBER Working Paper No. 17197

July 2011

JEL No. E32,E51,G12,G32

\begin{abstract}
$\underline{\text { ABSTRACT }}$
We show that the credit quality of corporate debt issuers deteriorates during credit booms, and that this deterioration forecasts low excess returns to corporate bondholders. The key insight is that changes in the pricing of credit risk disproportionately affect the financing costs faced by low quality firms, so the debt issuance of low quality firms is particularly useful for forecasting bond returns. We show that a significant decline in issuer quality is a more reliable signal of credit market overheating than rapid aggregate credit growth. We use these findings to investigate the forces driving time-variation in expected corporate bond returns.
\end{abstract}

\author{
Robin Greenwood \\ Harvard Business School \\ Baker Library 267 \\ Soldiers Field \\ Boston, MA 02163 \\ and NBER \\ rgreenwood@hbs.edu
}

Samuel G. Hanson

Harvard Business School

Soldiers Field Road

Boston, MA 02163

shanson@hbs.edu

An online appendix is available at:

http://www.nber.org/data-appendix/w17197 


\section{Introduction}

In most modern accounts of the credit cycle, fluctuations in the quantity of credit are driven by time-varying financing frictions, due to changes in borrowers' net worth or in bank capital (Bernanke and Gertler (1989); Holmstrom and Tirole (1997); Kiyotaki and Moore (1997); and Kashyap, Stein, and Wilcox (1993)). Notably absent from these accounts is the possibility that time-varying investor beliefs or tastes play a role in determining the quantity and allocation of credit. This absence is surprising given abundant evidence of historical periods - such as the 1980s junk bond era or the credit boom of 2004-2007 - when credit markets appear to have become overheated, potentially reflecting heightened investor risk appetites or over-optimism. ${ }^{1}$ During these periods, investors granted credit at low promised yields to borrowers of poor quality, and experienced low returns when these borrowers later defaulted and credit spreads widened. In this paper we show that this pattern of deteriorating issuer quality followed by low investor returns should be understood as a recurring feature of the credit cycle.

Our approach is to link patterns of corporate debt financing to time-series variation in the pricing of credit risk. The key insight is that broad changes in the pricing of credit risk disproportionately affect the financing costs faced by low credit quality firms. To the extent that firms issue more debt when credit is “cheap,” the debt issuance of low credit quality firms may then be a particularly useful barometer of financing conditions. Specifically, time-variation in debt issuer quality may be useful for forecasting corporate bond returns: following periods when debt issuers are of particularly poor credit quality credit assets should underperform.

To test this hypothesis, we form time-series measures of debt issuer quality. Our primary measure compares the average credit quality of firms with high debt issuance - proxied using each firm's expected default frequency - to the credit quality of firms with low debt issuance. A second measure is constructed from credit ratings: each year from 1926 to 2008, we compute the fraction of corporate bond issuance that is rated speculative grade. Building on Hickman (1958), Atkinson (1967), and Bernanke, Gertler, and Gilchrist (1996), we show that variation in issuer

\footnotetext{
${ }^{1}$ See Kaplan and Stein (1993) and Grant (1992) on the 1980s LBO and junk bond boom, Coval, Jurek, and Stafford (2009) on the 2000s structured finance boom, and Axelson, Jenkinson, Stromberg, and Weisbach (2010), Ivashina and Sun (2010) and Shivdasani and Wang (2009) on the 2000s leveraged loan and LBO boom.
} 
quality is a central feature of the credit cycle: when aggregate credit increases, the average quality of issuers deteriorates.

We use these measures of issuer quality to forecast the excess returns on corporate bonds. Following periods when issuer quality is poor, corporate bonds significantly underperform Treasury bonds of similar maturities. The degree of return predictability is large in both economic and statistical terms. The predictability is most striking for high yield bonds - with univariate $R^{2}$ statistics up to $30 \%$ at a 3-year horizon - but similar results obtain for investment grade bonds, albeit with diminished magnitude. We show that issuer quality has incremental forecasting power for corporate bond returns over and above traditional proxies for risk premia, including credit spreads, short-term interest rates, and the term spread. Furthermore, the quality of debt issuance is a better forecaster of excess corporate bond returns than the aggregate quantity of debt issuance, suggesting that the quantity of debt issuance responds to common shocks which are unrelated to the pricing of credit risk (e.g., common shocks to investment opportunities). In summary, our results demonstrate a high degree of predictability in corporate bond returns that is linked to the quality of corporate debt financing.

We then use these findings to shed light on the forces that drive time-series variation in expected corporate bond excess returns. We consider three potential sources of return predictability: (1) countercyclical variation in the rationally determined price of risk as would arise in consumption-based asset pricing models; (2) time-variation in intermediary risk tolerance in markets characterized by limited capital or other intermediary financing frictions; and (3) time-varying mispricing due to investor biases in evaluating credit risk over the cycle. In attempting to discriminate between these sources, we recognize that it is generally impossible to fully rule out one explanation or another. This is because theories of time-variation in expected returns are quite flexible and there is little reason to believe that just one channel is operational.

We first consider whether the results are consistent with consumption-based models in which markets are integrated and the rationally determined price of risk varies in a countercyclical fashion. For instance, investors' risk aversion may vary due to habit formation as in Campbell and Cochrane (1999). According to these explanations, investors are not 
systematically surprised when the bonds of low quality firms who often receive funding during booms later underperform.

Our measures of issuer quality are correlated with fluctuations in the business cycle, suggesting some promise for consumption-based asset pricing models. And, when included as controls in our return forecasting regressions, current and lagged macroeconomic conditions slightly attenuate the effects of issuer quality. However, a major stumbling block for these models is that we forecast significantly negative excess returns in a number of sample years. Because credit assets typically underperform Treasuries during bad economic times, rational consumption-based models would always predict positive expected excess returns. Furthermore, our quality measures are disconnected from traditional forecasters of the equity premium, and do not forecast excess stock returns, cutting against the idea that issuer quality proxies for a rationally time-varying price of risk in fully integrated stock and bond markets.

Another source of variation in expected returns could stem from changes in intermediary risk tolerance in markets characterized by limited capital. For example, a number of authors have argued that fluctuations in intermediary equity capital may be tied to risk premia. We examine a number of proxies for intermediary balance sheet strength, including lagged intermediary capital ratios and balance sheet growth. Several of these measures are correlated with issuer quality in the expected direction (e.g., issuer quality tends to be poor when insurers - who are large holders of corporate bonds - have high equity capital ratios). However, the forecasting power of issuer quality is not impacted by the addition of intermediary-related controls.

A slightly different intermediary-based explanation is suggested by Rajan (2005), who argues that agency problems may encourage delegated investors to "reach for yield,” buying riskier assets with high promised yields when riskless interest rates are low. Consistent with this idea, we show that issuer quality declines when yields on Treasury bonds are low or have recently fallen. On the other hand, interest rate controls do little to affect the forecasting power of issuer quality in our regressions.

A third source of variation in expected returns could come from biased investor beliefs. Specifically, investors may make biased assessments of default probabilities, leading to time- 
varying mispricing of credit. A natural bias might stem from over-extrapolation of past default rates or bond returns. For example, following a string of years in which few firms default, investors may underestimate future default probabilities, leading them to bid up the prices of risky corporate bonds. As a result, investors are systematically surprised by periods of elevated corporate defaults, resulting in sharp declines in corporate bond prices.

Explanations that appeal investor over-extrapolation are attractive because they allow for negative expected excess returns, consistent with our findings. And, while it is difficult to measure investors' beliefs directly, the extrapolation story predicts that issuer quality should decline following periods of low defaults or high credit returns. This pattern emerges quite strongly in the data, suggesting that the recent experience of credit market investors may play a role in shaping investors' expectations or tastes.

In summary, it is not possible to fully pin down the forces that drive variation in expected returns. However, the evidence suggests that mispricing may play a role - i.e., investor “sentiment” may play a role in driving credit cycles. And, if we adopt this interpretation, a significant erosion in issuer quality may be a useful signal of credit market overheating.

The plan for the paper is as follows. Section II motivates our empirical strategy. Section III describes the data and the construction of our issuer quality measures, which we tie to historical accounts of the credit cycle. Section IV presents our main return forecasting results. We also discuss the link between issuer quality and aggregate credit growth, affirming the central importance of issuer quality from the standpoint of credit cycles. Section V evaluates competing explanations for the predictable variation in excess returns that we document. Section VI concludes.

\section{Empirical Design}

Here we develop a simple reduced-form model in which corporate debt issuance responds to changes in the pricing of credit. The model explains why debt issuer quality may be useful for forecasting excess credit returns. The model pinpoints the circumstances under which quality is a better barometer of the credit market than the quantity of issuance; it also explains why quality may contain information about expected returns beyond what is revealed by credit spreads. 


\section{A. A reduced-form model of credit spreads and debt issuance}

Following Duffie and Singleton (1999), credit spreads (the difference between corporate bond yields and risk-free yields of the same maturity) are equal to expected credit losses plus expected excess returns. At this point we can be agnostic about what drives variation in expected returns: it might be a rationally time-varying credit risk premium, time-varying mispricing, or both. As a simple reduced form, we write the credit spread $s_{\theta, t}$ for firms of type $\theta$ as

$$
s_{\theta, t}=\pi_{\theta, t}+\beta_{\theta} \delta_{t}
$$

where $\pi_{\theta, t}$ is the time-varying probability of default, $\delta_{t}$ denotes the time-varying expected return on credit assets, and $\beta_{\theta}$ is the exposure of type $\theta$ firms to the market-wide pricing credit risk. Thus, the expected excess return on bonds of type $\theta$ is

$$
E_{t}\left[r x_{\theta, t+1}\right]=\beta_{\theta} \delta_{t}
$$

For simplicity, we assume that $\pi_{\theta, t}$ does not directly affect expected excess returns. Since default probabilities $\pi_{\theta, t}$ vary over time, equations (1) and (2) capture the idea that spreads mean different things at different times: spreads can be low because default probabilities are low or because expected excess returns are low.

For simplicity, suppose firms are either low default risk $L$ or high default risk $H$, with $\pi_{L, t}<\pi_{H, t}$ for all $t$. Our central assumption is that $\beta_{L}<\beta_{H}$. This means that the bonds of high default risk firms are more heavily exposed to market-wide changes in the pricing of credit risk.

Firms of type $\theta$ choose their debt issuance $d_{\theta, t}$ (or leverage) by trading off the benefits of issuing additional cheap debt against the costs of deviating from their target capital structure, as in Stein (1996). Target capital structure has two independent components: a part $\xi_{t}$ that is common to all firms and a part $\varepsilon_{\theta, t}$ that is specific to firms of type $\theta$. A variety of factors unrelated to expected returns may cause target leverage to fluctuate, such as changes in investment opportunities. We assume that firms choose their issuance to solve

$$
\begin{aligned}
\max _{d_{\theta, t}}\left\{\left(\pi_{\theta, t}-s_{\theta, t}\right) \cdot d_{\theta, t}-(\gamma / 2) \cdot\left(d_{\theta, t}-\left(\xi_{t}+\varepsilon_{\theta, t}\right)\right)^{2}\right\} \\
=\max _{d_{\theta, t}}\left\{-\beta_{\theta} \delta_{t} \cdot d_{\theta, t}-(\gamma / 2)\left(d_{\theta, t}-\left(\xi_{t}+\varepsilon_{\theta, t}\right)\right)^{2}\right\},
\end{aligned}
$$


where $\gamma$ reflects the cost of deviating from target leverage. The optimal choice of $d_{\theta, t}$ is given by

$$
d_{\theta, t}^{*}=\xi_{t}+\varepsilon_{\theta, t}-\left(\beta_{\theta} / \gamma\right) \cdot \delta_{t}
$$

so firms borrow more when the expected returns on credit assets are low. ${ }^{2}$ A classical justification for this reduced-form appeals to familiar Q-theory logic: the optimal scale of corporate investment, and hence debt issuance, rises when rationally required returns decline.

The logic of our identification strategy can be seen immediately from equation (4). Debt issuance is driven by changes in expected returns and changes in target leverage. Since $\beta_{L}<\beta_{H}$, fluctuations in expected returns $\delta_{t}$ have a larger impact on the issuance of high default risk firms than on the issuance of low default risk firms. Changes in target leverage are not informative about expected returns and have a common component that is shared by all firms. Thus, it is useful to examine the difference in debt issuance between high- and low-default risk firms.

Now, suppose that half of the firms are low default risk and the other half are high default risk, then equation (4) implies that the total quantity of debt issuance is

$$
d_{H, t}^{*}+d_{L, t}^{*}=\left(2 \xi_{t}+\varepsilon_{H, t}+\varepsilon_{L, t}\right)-\left(\left(\beta_{H}+\beta_{L}\right) / \gamma\right) \cdot \delta_{t}
$$

A proxy for the issuer quality mix is the difference in debt issuance between high and low default risk firms

$$
d_{H, t}^{*}-d_{L, t}^{*}=\left(\varepsilon_{H, t}-\varepsilon_{L, t}\right)-\left(\left(\beta_{H}-\beta_{L}\right) / \gamma\right) \cdot \delta_{t} .
$$

By looking at the quality of issuance, we remove the impact of the common factor $\xi_{t}$ which affects the issuance of all firms. Thus, the quality mix helps isolate the information that issuance contains about expected returns.

\section{B. Forecasting returns using issuance quantity and quality}

Under these assumptions, both quantity $\left(d_{H, t}^{*}+d_{L, t}^{*}\right)$ and quality $\left(d_{H, t}^{*}-d_{L, t}^{*}\right)$ will negatively forecast excess returns in a univariate regression. In a bivariate forecasting regression

\footnotetext{
2 The idea that firms can back out the component of credit spreads that is due to any time-varying mispricing may seem objectionable: it seems implausible that firms could have an informational advantage over sophisticated investors in forecasting broad changes in spreads. However, as emphasized by Greenwood, Hanson, and Stein (2010), firms may have an institutional advantage in exploiting aggregate mispricing even if they have no informational advantage. Sophisticated investors are often subject to limits of arbitrage which may be particularly relevant in the case of market-wide mispricing. By contrast, operating firms can exploit this kind of mispricing by adjusting their capital structures without the fear of performance-based withdrawals.
} 
that includes both quantity and quality, the coefficients on both variables will be negative so long as $\sigma_{\varepsilon}^{2}>0$. However, quality becomes more informative than quantity as $\sigma_{\xi}^{2}$ grows large (the Internet Appendix contains the relevant calculations.) Intuitively, examining the quality mix should be particularly informative if aggregate debt issuance has an important time-series component that is unrelated to future returns. For example, if aggregate debt issuance fluctuates significantly due to shocks to aggregate investment opportunities, then the quality mix of issuance may be a better predictor of returns. The model also suggests that the results will be strongest when forecasting the returns of low-grade bonds which have the greatest exposure to market-wide changes in the pricing of credit.

\section{Forecasting returns using spreads and issuance quality}

Credit spreads positively forecast excess returns on corporate bonds. Should issuer quality have incremental forecasting power for returns beyond spreads? In a multivariate forecasting regression of excess returns on credit spreads and issuer quality, the coefficient on spreads is positive and the coefficient on $d_{H, t}^{*}-d_{L, t}^{*}$ is negative. This is because both spreads and issuer quality are affected by factors other than expected returns. For instance, as the time-series volatility of default probabilities $\sigma_{\pi}^{2}$ (i.e., fundamentals) grows large, spreads become less informative about $\delta_{t \cdot}{ }^{3}$

\section{Measuring issuer quality empirically}

How should we measure issuer quality in the data? A first approach which follows directly from equation (6) is to classify firms as either high or low default risks and then compare the debt issuance of these two groups, i.e., $d_{H, t}^{*}-d_{L, t}^{*}$. A related idea is to compute the share of debt issuance accounted for by high default risk firms, i.e., $d_{H, t}^{*} /\left(d_{H, t}^{*}+d_{L, t}^{*}\right)$. It may also be useful to construct measures which reflect the continuous nature of firm default risk. Thus, a third measure compares the default risk of high debt issuers with that of low debt issuers each period

\footnotetext{
${ }^{3}$ To see the intuition, consider the related exercise of forecasting stock returns using equity issuance and the dividend yield, $D / P$. Suppose a Gordon growth model holds, so $D / P$ reflects expected returns and dividend growth - i.e., $D / P=R-G$. If issuance responds mechanically to $D / P$, it will have no incremental forecasting power. If, however, issuance responds differentially to changes in $R$, it may contain additional information beyond $D / P$.
} 


$$
\operatorname{ISS}_{t}=E_{t}\left[\beta_{i} \mid \operatorname{High~}_{i, t}^{*}\right]-E_{t}\left[\beta_{i} \mid \operatorname{Low}_{i, t}^{*}\right] \text {, }
$$

where we now allow quality $\beta_{i}$ and debt issuance vary continuously across firms. This construction parallels the equity issuance-based "characteristic spreads” used in Greenwood and Hanson (2011). It is straightforward to show that all three measures are decreasing in expected returns $\delta_{t}$. While $I S S_{t}$ is the measure we emphasize in the majority of the paper, we show that our findings are not sensitive to the specific method we use to measure issuer quality.

\section{Measuring Debt Issuer Quality}

A. Compustat-based measures of issuer quality: 1962-2008

Following the above discussion, we compare the credit quality of firms issuing large amounts of debt to that of firms issuing little debt or who are retiring debt. Specifically, in each year $t$, we compute

$$
I S S_{t}^{E D F}=\frac{\sum_{i \in \text { High d d }_{i, t}} E D F_{i, t}}{N_{t}^{\text {High d }} d_{i, t}}-\frac{\sum_{i \in \text { Low d }_{i, t}} E D F_{i, t}}{N_{t}^{\text {Low d d }} \text { i, }},
$$

where EDF is an estimate of the firm's default probability, $d_{i, t}=\Delta D_{i, t} / A_{i, t-1}$ denotes debt issuance, and $N$ denotes the number of firms. Debt issuance is the change in assets minus the change in book equity from Compustat, scaled by lagged assets. ISS ${ }^{E D F}$ compares the average default probability of high net debt issuers (net debt issuance in the top NYSE quintile) with the default probability of low net debt issuers (net debt issuance in the bottom NYSE quintile). Thus, $I S S^{E D F}$ takes on high values when debt issuers are of relatively poor credit quality.

$E D F$ is the Merton (1974) expected default frequency, computed following Bharath and Shumway (2008). ${ }^{4}$ A simple way to think of $E D F$ is that it is a statistical equivalent of a credit rating, albeit one that we can compute reliably for a larger sample of firms starting in 1963 (the correlation between EDF decile and S\&P credit ratings is 0.54 for firm-years with a valid rating in Compustat from 1985-2008). Highly levered firms with high asset volatility and low expected

\footnotetext{
${ }^{4}$ For firm $i$ in year $t, E D F_{i, t}=\Phi\left[-\left(\ln \left[\left(E_{i, t}+F_{i, t}\right) / F_{i, t}\right]+\mu_{i, t}-0.5 \sigma_{V_{i, t}}^{2}\right) / \sigma_{V_{i, t}}\right]$ where $E_{i, t}$ is the market value of equity, $F_{i, t}$ is the face value of debt (computed as short-term debt plus one-half long-term debt), $\mu_{i, t}$ is the asset drift (estimated using the prior 12-month stock return), $\sigma_{V_{i, t}}$ is the asset volatility (estimated as $\sigma_{V_{i, t}}=\left(E_{i, t} /\left(E_{i, t}+F_{i, t}\right)\right) \sigma_{E_{i, t}}+\left(F_{i, t} /\left(E_{i, t}+F_{i, t}\right)\right)\left(0.05+0.25 \sigma_{E_{i, t}}\right)$ where $\sigma_{E_{i, t}}$ is the annualized volatility of monthly stock returns over the prior 12 months), and $\Phi[\cdot]$ is the standard normal CDF.
} 
returns have the highest EDFs. Firms with high EDFs also tend to be small and young, do not pay dividends, have high leverage, and have low interest coverage. Naturally, these firms also have high estimated default probabilities based on other forecasters, such as the Shumway (2001) bankruptcy hazard rate. Debt issues, $E D F$, and several alternate measures of firm credit quality are summarized in Panel A of Table 1, with the details of their construction given in the Internet Appendix. EDF is close to zero for the median firm, while the mean EDF is 6\%.

When substituting a firm's EDF into equation (8), we follow convention and use NYSE deciles rather than the raw values. Using deciles minimizes the influence of outlier firms and avoids the possibility of picking up compositional shifts in the set of listed firms or secular trends. ${ }^{5}$ It also makes the units easy to interpret: $I S S_{t}^{E D F}=1$ means that firms with high net debt issuance had $E D F$ s that were on average one decile higher than firms with low net debt issuance.

We plot $I S S^{E D F}$ in Figure 1 and provide summary statistics for the time series in Table 1. $I S S^{E D F}$ was high (i.e., high debt issuers were of relatively poor quality) in the mid-to-late 1960s, 1973, 1978, the mid-to-late 1980s, 1997-1998, and again in 2005-2007. ISS ${ }^{E D F}$ drops sharply in 1970-1971, 1975-1976, the early 1990s, 2001-2002, and finally in 2008.

Figure 1 also shows the relationship between $I S S^{E D F}$ and the business cycle. The shaded bars denote NBER recessions. ISS ${ }^{E D F}$ tends to be low in recessions and high in expansions. However, this relation is not exact and the lead-lag relationship between the business cycle and $I S S^{E D F}$ varies over time. For instance, $I S S^{E D F}$ falls during many recessions, but rises during the 1982 recession as the 1980s high yield boom was getting underway. The series also tends to peak before recessions, but occasionally peaks after the economy is already in recession. We can remove the influence of the business cycle by regressing $I S S^{E D F}$ on the output gap (HodrickPrescott (1997) filtered log real GDP) and saving the residuals. This orthogonalized series, shown as a dashed line in Panel B, still captures the same peaks and troughs of the original series, consistent with the idea that the credit cycle is somewhat distinct from the business cycle.

Our time series of issuer quality corresponds closely to historical accounts of credit

\footnotetext{
${ }^{5}$ For example, if we wanted to see whether issuance was concentrated among large firms, it would make little sense to compute the average size of high issuers as the cross-sectional dispersion of size has increased over time. A limitation of using deciles is that we throw out information about changes in the cross-sectional dispersion of $E D F_{i, t}$.
} 
booms and busts. For example, Grant (1992) describes the credit boom of the late 1960s, when our ISS ${ }^{E D F}$ series reaches its sample peak. This period saw booming corporate bond issuance and the rise of the short-term commercial paper market, which grew from $\$ 10$ billion in 1966 to over $\$ 40$ billion by early 1970 . The boom came to an abrupt end following the Penn Central commercial paper default of June 1970. Officials at the Federal Reserve Bank of New York noted the "deterioration in the quality of outstanding paper" in the run-up to Penn Central. These events are reflected in the sharp drop in ISS ${ }^{E D F}$ between 1968-1969 and 1970-1971.

The decline of issuer quality during the 1980s junk bond boom has been noted by a number of authors (Grant (1992) and Kaplan and Stein (1993)). Klarman (1991) notes that financier Michael Milken marketed new issue junk bonds on the assumption that their default rates would be similar to those of recent high yield issues. However, default rates had been low due to strong economic growth in an environment of declining interest rates. Klarman argues that the denominator in the default rate calculation soared during the issuance boom, leading investors to underestimate the likelihood of future defaults (Asquith, Mullins, and Wolff (1989)).

The robust credit markets of the mid-to-late 1990s and 2004-2007 are by now familiar. However, ISS ${ }^{E D F}$ is unlikely to capture the full extent of the 2004-2007 boom, because it is based on corporate credit, whereas much of the credit growth during this period was in residential mortgages and structured products. While we do not expect $I S S^{E D F}$ to capture the full scale of this activity, the basic arc of the boom is apparent in Figure 1.

Panel B of Table 1 also summarizes alternate time-series measures of issuer quality, constructed similarly to $I S S^{E D F}$. We follow the same procedure as in equation (8), but use different firm characteristics to proxy for credit quality. For example, ISS ${ }^{\text {Intcov }}$ is the difference between the average interest coverage (decile) of high and low debt issuers. In each case, we order characteristics so that high values of the ISS variable indicate years in which lower credit quality firms are issuing debt. These measures of quality are all highly correlated over time.

\section{B. The high yield share: $1926-2008$}

A second quality measure can be formed using the credit ratings assigned to new corporate bond issues. We define the high yield share as the share of nonfinancial corporate bond 
issuance in each year with a high yield rating from Moody’s

$$
\text { HYS }_{t}=\frac{\sum_{\text {HighYield }} B_{i, t}}{\sum_{\text {HighYield }} B_{i, t}+\sum_{\text {InvGrade }} B_{i, t}},
$$

where $B_{i, t}$ denotes the principal value of bond $i$ issued in year $t .^{6}$ In our forecasting regressions, we take the log of the raw share so that our regression coefficients can be interpreted as the change in returns following a one percent change in HYS. ${ }^{7}$ We use the Mergent Fixed Income Security Database (FISD) to construct HYS from 1983-2008. We extend the series from 19261965 using data from NBER studies by Hickman (1960) and Atkinson (1967) who report aggregate issuance by credit rating based on a compilation of bond issues from Moody's Bond Surveys. Aggregate issues by credit rating are not available from 1966-1982, so we hand-collect information on bond offerings from weekly editions of these books. ${ }^{8}$

Figure 2 plots HYS alongside ISS ${ }^{E D F}$ for comparison. Similar to ISS ${ }^{E D F}$, HYS takes on high values when issuer quality is poor. The data show a small high yield debt boom in the late 1950s and early 1960s, and a more substantial boom in the late 1960s. Corporate bond issuers were of particularly low quality in the late 1980s, in 1997 and 1998, and again in 2004 and 2005. There appears to be a regime shift between the first and second halves of the sample: the level and volatility of HYS are much higher starting in the early 1980s. The correlation between HYS and $I S S^{E D F}$ is 0.47 prior to 1982 , and 0.58 after 1982 .

The advantage of HYS is its simplicity. However, there are several reasons to prefer $I S S^{E D F}$. First, ISS ${ }^{E D F}$ reflects a broader measure of debt issues, including both loan and bond market financing. This means that unlike HYS, $I S S^{E D F}$ is not be impacted by secular shifts in the

\footnotetext{
${ }^{6}$ High yield bonds are those rated Ba1 or lower by Moody's or BB+ or lower by SS\&P. For simplicity, we use the S\&P nomenclature (e.g., AAA, AA, A, BBB, BB, B, and C) throughout, even when working with Moody's data.

${ }^{7}$ We use $\log (H Y S)$ because it provides a good fit, but qualitatively similar results obtain if we forecast returns using HYS. To compute $\log (H Y S)$, we need to address the fact that HYS $=0$ in 1974. To do so, we set HYS equal to 0.0024 for 1974 before applying the log transformation (0.0024 is the second lowest value of HYS observed in sample). However, our treatment of this single observation does not play an important role in driving our results.

${ }^{8}$ FISD is the current incarnation of the Moody's Bond Survey, so we are using the same primary source throughout. We start using FISD in 1983 because FISD only contains bonds that mature in 1990 or later. So long as speculative and investment grades issues have similar maturity distributions, this truncation should impart no bias to HYS. We exclude financials, asset-backed securities, sovereigns, and exchange offers to preserve comparability with Hickman (1960) and Atkinson (1967). The amount of bond offerings by Moody's rating from 1926-1943 is from Table 52 of Hickman (1960) and data from 1944-1965 is from Table B-1 of Atkinson (1967). Following Atkinson and Hickman, we include convertible issues from 1966-1982. Prior to the surge in high yield issuance in the 1980s, many speculative grade issues contained conversion features.
} 
relative sizes of the markets for low-grade bonds and low-grade loans. Since the sizes of these markets have fluctuated over time - the most prominent example being the rapid growth of the high yield bond market in the early 1980s - this is a major strength of $I S S^{E D F}$. Indeed, the level of HYS is considerably lower prior to the early $1980 \mathrm{~s}^{9}$ Second, if loan and bond markets are partially integrated components of the broader corporate credit market, measures based on total debt issuance (loans plus bonds) may be more informative about future bond returns than measures based solely on bond issuance. Specifically, if firms willingly substitute between loans and bonds, isolated shocks to bank loan supply would induce a positive relationship between bond issuance and expected excess bond returns. However, the relationship between total debt issuance and expected excess bond returns would remain negative, even in the presence isolated loan supply shocks. ${ }^{10}$ Third, ISS ${ }^{E D F}$ holds constant the definition of firm quality. HYS, in contrast, relies on the assumption that the meaning of credit ratings has remained constant. However, Blume, Lim, and MacKinlay (1998) and Baghai, Servaes, and Tamayo (2010) argue that the agencies have become more conservative in assigning ratings since the late 1970s. Fourth, ISS ${ }^{E D F}$ is based on net rather than gross debt issuance, thus better capturing changes in the financial position of low quality firms.

Figure 2 illustrates a final limitation of HYS as a measure of issuer quality: it can be unduly volatile in years in which total issuance (the denominator in equation (9)) is particularly low. This is most problematic in 1933 - the historical low point for total issuance, representing a near collapse of the corporate bond market. Because investment grade issuance fell even more dramatically than high yield issuance in 1933, HYS spikes to its sample maximum at the nadir of the Great Depression. While we use the full time-series of HYS in the analysis that follows, we note that removing this single outlier significantly strengthens our forecasting results.

\footnotetext{
${ }^{9}$ We can compute bonds outstanding as a share of total loans and bonds for non-financial corporations from Table 102 of the Flow of Funds. This "bond share" fell steadily from 52\% in 1962 to 39\% in 1984 and then gradually rose again to $61 \%$ by 2003. This trend reversed from 2004-2008 as the bond share again fell to 56\%, reflecting the rapid growth of the leveraged loan market.

10 To see why, suppose that lending standards are relaxed, while bond investment standards remain unchanged. Since corporations substitute between loans and bonds (see e.g., Becker and Ivashina (2010)), banks' willingness to grant cheap credit would raise loan issuance, lower bond issuance, and lower expected bond excess returns. However, total debt issuance would rise. In summary, assuming partial substitutability between bonds and loans, total debt issuance is likely to be better reflection of broad credit supply, which in turn drives expected excess bond returns. Empirically, it appears that ISS ${ }^{E D F}$ partially reflects changes in lending standards: changes in ISS ${ }^{E D F}$ are -0.51 correlated with the Federal Reserve's Senior Loan Officer Opinion Survey of changes in the stricture of bank lending standards from 1967-1983 (see Lown and Morgan (2006)) and 1990-2008.
} 


\section{Returns and other data}

Our remaining time series are summarized in Panel D of Table 1. Short-term government bond yields $\left(y_{S, t}^{G}\right)$ and the term spread $\left(y_{L, t}^{G}-y_{S, t}^{G}\right)$ are from Ibbotson. The credit spread ( $y_{L, t}^{B B B}-y_{L, t}^{G}$ ) is the difference between the log yield of the Moody's BBB corporate index and the log long-term government bond yield from Ibbotson. Business cycle controls include industrial production growth from the Federal Reserve, real aggregate consumption growth from the BEA National Income and Product Accounts, and a dummy variable indicating whether the year is classified as a recession by the NBER. As an alternate business cycle control, we use HodrickPrescott (1997) filtered log real GDP as a measure of the output gap. We also use the consumption wealth ratio (cay) from Lettau and Ludvigson (2001) and the eight principal components that Ludvigson and Ng (2010) extract from 130 macroeconomic time series.

Returns on high yield bonds are from Morningstar/Ibbotson from 1927-1982 and from Barclays Capital (formerly Lehman Brothers) starting in 1983. We construct high yield excess returns by subtracting the log return on intermediate Treasuries from Ibbotson: $r x_{t+1}^{H Y}=r_{t+1}^{H Y}-r_{t+1}^{G}$. Intermediate Treasuries (with a maturity of approximately 5 years) are the appropriate benchmark for high yield bonds since the average duration on the Barclay's high yield index is just under 5 years. ${ }^{11}$ Excess returns on BBB-rated corporate bonds $\left(r x_{t+1}^{B B B}=r_{t+1}^{B B B}-r_{t+1}^{G}\right)$ and AAA-rated bonds $\left(r x_{t+1}^{A A A}=r_{t+1}^{A A A}-r_{t+k}^{G}\right)$ are calculated in a similar fashion using Morningstar/Ibbotson data from 1927-1989 and Barclays data beginning in 1990. We compute 2- and 3- year cumulative log excess returns by summing 1-year log excess returns.

\section{Issuer quality and excess corporate bond returns}

\section{A. Univariate forecasting regressions}

Figure 3 shows our main result. We plot ISS ${ }^{E D F}$ against cumulative high yield excess returns over the following 2 years. Returns are plotted in reverse scale, so the negative

\footnotetext{
${ }^{11}$ Ibbotson bond return data are also used by Keim and Stambaugh (1986), Fama and French (1989) and Krishnamurthy and Vissing-Jorgensen (2010). Ibbotson returns are based on a sample of corporate bonds with a remaining maturity greater than one year. The Barclays Capital U.S. High Yield Index covers the universe of U.S. dollar high yield corporate debt. Index-eligible issues must be fixed-rate, non-convertible, have a remaining maturity of at least one year, and have an outstanding par value of at least \$150 million. The value-weighted index return includes the price return that is realized upon the event of default.
} 
correlation appears positive visually. The correlation between the two series is -0.51 . Simply put, periods of poor issuer quality are followed by low excess returns on corporate bonds.

Table 2 shows forecasting regressions of cumulative excess returns on quality measures

$$
r x_{t+k}^{H Y}=a+b \cdot X_{t}+u_{t+k}
$$

where $k$ denotes a forecast horizon of 1-, 2-, or 3-years and $X$ is either $I S S^{E D F}$ or $\log (H Y S)$. Moving from left to right, we present forecasting regressions for $I^{E S}{ }^{E D F}$ for 1962-2008 and the 1983-2008 subsample, and HYS for 1926-2008 and the 1983-2008 subsample. We isolate the 1983-2008 period which corresponds to the modern high yield bond market. Moving from top to bottom, the three panels show separate regressions for the excess returns on high yield, BBBrated, and AAA-rated corporate bonds. Here and in subsequent tables, $t$-statistics for $k$-year regressions are based on Newey-West (1987) standard errors, allowing for serial correlation up to $k$ lags. A full discussion of statistical inference in this context is in the Internet Appendix.

The top-left regression in Panel A shows that $I S S^{E D F}$ has an $R^{2}$ of $12 \%$ for high yield excess returns at a 1-year horizon. The coefficient of -9.534 implies that a one standard deviation rise in $I S S^{E D F}$ ( 0.47 deciles) lowers excess high yield returns by $4.5 \%$ over the following year, about 0.35 standard deviations. Thus, the level of predictability is strong in economic terms. ${ }^{12}$

As we lengthen the forecast horizon from 1-year to 3-years, the $R^{2}$ grows to $29 \%$ and the coefficients increase in magnitude. Specifically, the coefficient on ISS ${ }^{E D F}$ is -9.534 at a 1-year horizon, -15.254 at a 2-year horizon, and -17.301 at a 3-year horizon. In untabulated results, we extend this analysis to longer horizons, estimating (10) for horizons up to six years. The forecasting power is concentrated in the first two years, with some additional power at three years, after which it levels off.

Moving down Table 2, the coefficients in Panel A for high yield bonds can be compared to those for BBB-rated and AAA-rated bonds in Panels B and C. The coefficient on ISS ${ }^{E D F}$ declines in magnitude from -9.534 when forecasting 1-year high yield returns, to -5.311 when forecasting BBB returns, and -2.278 when forecasting AAA returns. This pattern of coefficients,

\footnotetext{
${ }^{12}$ As can be seen in Figure 3, high levels of $I S S^{E D F}$ predict low or negative high yield excess returns. Conversely, low levels of ISSEDF predict large positive excess returns. Furthermore, the impact of high and low values of ISS ${ }^{E D F}$ is roughly symmetric. Let $I S S_{t}^{+}=\max \left\{I S S_{t}-\overline{I S S}, 0\right\}$ and $I S S_{t}^{-}=\min \left\{I S S_{t}-\overline{I S S}, 0\right\}$. If we estimate $r x_{t+2}^{H Y}=a+b_{+} \cdot I S S_{t}^{+}+b_{-} \cdot I S S_{t}^{-}+u_{t+2}$, we obtain $b_{+}=-12.786(t=-2.30)$ and $b_{-}=-17.008(t=-3.24)$. However, the difference between $b_{+}$and $b_{-}$is not significant.
} 
apparent throughout Table 2, is consistent with the model in Section II in which lower-rated bonds have greater exposure to a common credit-related factor. Moving to the right, Table 2 shows that the forecasting power of $I S S^{E D F}$ is present in both the full 1962-2008 sample as well as the modern 1983-2008 subsample.

The right half of Table 2 shows specifications involving $\log (H Y S)$ as the predictor. Starting with the full 1926-2008 sample, the coefficient of -1.517 for 1-year returns implies that a one percent increase in HYS reduces high yield excess returns by $-1.517 \%$. In the 1983-2008 subsample, the corresponding coefficient is -11.483 , so the relation between HYS and subsequent returns is economically and statistically stronger than the full sample. More generally, because HYS was formed by splicing together four separate time-series, we estimate the forecasting regression for various additional subsamples in the Internet Appendix. The results for the individual subsamples are generally stronger than the full 1926-2008 sample results. (The single exception is the 1926-1943 period which is heavily influenced by the outlying 1933 observation.)

Overall, a consistent picture emerges whether we forecast returns using ISS ${ }^{E D F}$ or HYS and when we consider earlier or more recent subsamples.

\section{B. Multivariate forecasting regressions}

We now examine the incremental forecasting power of issuer quality over other potential predictors of excess corporate bond returns. Two sets of control variables are of interest. First, we want to know whether issuer quality has any forecasting power beyond common proxies for ex ante risk premia such as the term spread (Fama and French (1989)) or the T-bill yield (Fama and Schwert (1977)). Second, we want to understand to what extent the results in Table 2 are driven by firms responding to some degree of mean reversion in credit spreads or excess returns. If issuer quality were driven out by credit spreads, our findings might still be interesting from an economic perspective, but would be less useful for forecasting returns.

Is it reasonable to think that issuance could contain incremental information about returns that is not contained in other observables such as credit spreads? If managers respond naively to changes in credit spreads, then the answer is no. However, as suggested in Section II, spreads mean different things at different times: they may be wide because expected credit losses are 
high, or because expected returns are high. If managers issue more when they perceive credit as being "cheap" (i.e., expected returns are low), then issuance may contain information beyond spreads. The same logic can be extended to other observable variables. If credit valuations are multi-dimensional, then corporate issuance decisions may integrate these disparate factors into a single statistic that is informative about returns. If we could condition on all relevant observables, issuance might become redundant in a forecasting regression. In practice, it may be difficult for the econometrician to identify the full set of relevant conditioning variables.

Table 3 shows return forecasting regressions of the form

$$
r x_{t+k}^{H Y}=a+b \cdot X_{t}+c \cdot\left(y_{L, t}^{G}-y_{S, t}^{G}\right)+d \cdot y_{S, t}^{G}+e \cdot\left(y_{L, t}^{B B B}-y_{L, t}^{G}\right)+f \cdot r x_{t}^{H Y}+u_{t+k},
$$

where $X$ again denotes $I S S^{E D F}$ or $\log (H Y S)$. As before, we forecast 1-, 2- and 3-year cumulative excess returns on high yield bonds. Controlling for the term spread and the T-bill yield has little impact on the coefficient on ISS ${ }^{E D F}$. For example, in the univariate forecasting regression in Table 2, the slope coefficient on ISS ${ }^{E D F}$ is -9.534, and falls in magnitude to -7.636 when these controls are added. The effects of the control variables are even more modest at 2- and 3-year forecast horizons. In the case of HYS for the full-1926-2008 sample, the coefficient on $\log (H Y S)$ in the multivariate regressions actually larger in magnitude and more significant, than in the corresponding univariate regressions. In the 1983-2008 subsample, controlling for the credit spread and past high yield returns has a larger impact on the $\log (H Y S)$ coefficient at a 1-year horizon. However, once we extend the forecast horizon to 2- and 3-years, these controls have little impact on the estimates and $\log (H Y S)$ remains statistically significant.

\section{The quantity and quality of debt issuance over the credit cycle}

In this subsection, we discuss the relationship between aggregate credit growth, the quality of debt issuance, and excess corporate bond returns. There is no mechanical relationship between the quality of debt issuance and aggregate credit growth, yet it is natural to think the two would be positively correlated, and indeed such a relationship is predicted by our discussion in Section II. We show that while aggregate credit growth forecasts bond returns, focusing on the credit growth of low quality firms is even more powerful. Reminiscent of Hickman (1958), Atkinson (1967), and Bernanke, Gertler, and Gilchrist (1996), this exercise suggests that 
variation in credit quality is a defining feature of the credit cycle.

We start by documenting the correlation between quantity and quality. Figure 4 shows the strong correlation between issuer quality and aggregate credit growth. We calculate aggregate debt growth, $\Delta D_{\text {Agg }} / D_{\text {Agg }}$, as the change in debt amongst non-financial Compustat firms, scaled by the lagged debt of firms reporting in successive years. The correlation between $I S S^{E D F}$ and $\Delta D_{\text {Agg }} / D_{\text {Agg }}$ is 0.45 . $^{13}$ Another way to illustrate the relationship between aggregate credit growth and issuer quality is to group Compustat firms into EDF quintiles, compute aggregate debt growth for each group, and then regress each debt growth series (denoted $\Delta D_{1} / D_{1}$ to $\left.\Delta D_{5} / D_{5}\right)$ on aggregate debt growth, $\Delta D_{\text {Agg }} / D_{\text {Agg. }}$. This exercise shows that $\Delta D_{5} / D_{5}$ has the largest loading on $\Delta D_{\text {Agg }} / D_{\text {Agg }}$ with $b=1.31(t=6.80)$, while $\Delta D_{1} / D_{1}$ has smallest loading, with $b$ $=0.71(t=8.13)$. Thus, if aggregate debt grows by $1.0 \%$, the debt of high quality firms grows by 0.7\%, while debt at low quality firms grows by $1.3 \%$.

A number of previous studies use corporate securities issuance to forecast returns (e.g., Loughran and Ritter (1995)). ${ }^{14}$ It is natural to ask whether there is anything special about issuer quality per se - i.e., is there information in who is borrowing over and above the total quantity of borrowing? In Table 4, we compare the forecasting power of issuer quality with that of aggregate credit growth. As argued in Section II, if debt issuance is partially driven by time variation in expected excess returns, the quantity and quality of debt issuance should both negatively forecast returns. However, if uninformative common shocks affect the issuance of all firms, we might expect issuer quality to outperform aggregate credit growth in a horserace.

Table 4 shows forecasting regressions of cumulative 2-year high yield excess returns without controls in Panel A and with controls in Panel B. The first three columns compare the forecasting power of $I S S^{E D F}$ to aggregate credit growth from Compustat, $\Delta D_{\text {Agg }} / D_{\text {Agg. }}$ While $\Delta D_{\text {Agg }} / D_{\text {Agg }}$ negatively forecasts returns, the horserace in column (3) shows that $\Delta D_{\text {Agg }} / D_{\text {Agg }}$ has little incremental forecasting power over and above $I S S^{E D F}$.

\footnotetext{
${ }^{13}$ Aggregate credit growth for non-financial corporations can also be calculated from Table 102 of the Flow of Funds. The correlation between ISS ${ }^{E D F}$ and this measure of credit growth is 0.68 .

${ }^{14}$ See also Fama and French (2008), and Pontiff and Woodgate (2008) for firm-level stock returns; Baker and Wurgler (2000) and Greenwood and Hanson (2011) for equity market and equity-factor returns; and Baker, Greenwood, and Wurgler (2003) for excess government bond returns.
} 
In a related exercise, columns (4) to (8) of Table 4 compare the forecasting power of debt growth for firms in $E D F$ quintiles 1 to 5 , denoted $\Delta D_{1} / D_{1}$ to $\Delta D_{5} / D_{5}$. To preserve comparability across columns, each series is standardized to have mean zero and standard deviation one. The table shows that debt growth amongst low quality firms contains the most valuable information about future corporate bond returns. Specifically, moving across columns (4)-(8), the economic and statistical significance rises as we consider debt growth of lower quality firms. For example, a one standard deviation rise in $\Delta D_{1} / D_{1}$ lowers returns by $3.47 \%$ over the following 2 years, while a one standard deviation in $\Delta D_{5} / D_{5}$ lowers returns by $7.09 \%$. When we include time-series controls in Panel B, debt growth of high quality firms $\left(\Delta D_{1} / D_{1}\right.$ and $\left.\Delta D_{2} / D_{2}\right)$ is only marginally significant whereas that of low quality firms $\left(\Delta D_{4} / D_{4}\right.$ and $\left.\Delta D_{5} / D_{5}\right)$ remains highly significant.

We can also include debt growth among high and low quality firms jointly as predictive variables. In the horserace between $\Delta D_{1} / D_{1}$ and $\Delta D_{5} / D_{5}$ shown in column (9), only $\Delta D_{5} / D_{5}$ remains significant. Alternately, we can examine the difference in debt growth between low quality and high quality firms, $\Delta D_{5} / D_{5}-\Delta D_{1} / D_{1}$. This construction, which corresponds to $d_{H, t}^{*}-d_{L, t}^{*}$ in equation (6), is a different way to measure issuer quality. ${ }^{15}$ As shown in column (10), $\Delta D_{5} / D_{5}-\Delta D_{1} / D_{1}$ negatively forecasts future returns, and this remains true if we control for debt growth at high quality firms in column (11). The bottom line is that much of the forecasting power of aggregate credit growth derives from credit growth at the lowest quality firms. ${ }^{16}$

\section{Time-series robustness}

Table 5 shows robustness specifications with and without the usual suite of time-series controls (the yield spread, the T-bill yield, the credit spread, and lagged excess high yield returns). Our basic result holds in a variety of subsamples, including pre-1983, post-1983, and dropping 2008-2009. Although Compustat has less reliable coverage prior to 1962, we can also

\footnotetext{
${ }^{15} I S S^{E D F}$ compares the EDFs of high and low debt issuance firms. By contrast, $\Delta D_{5} / D_{5}-\Delta D_{1} / D_{1}$ compares the debt growth of high and low EDF firms: the correlation between this series and ISS ${ }^{E D F}$ is 0.52 .

${ }^{16}$ As shown in the Internet Appendix, the theme that low quality issuance is most useful for forecasting returns also emerges in our corporate bond issuance data. Specifically, we can compute the growth in high yield and investment grade issuance, $b_{t}^{H Y}=\ln \left[\left(B_{t}^{H Y}\right) /\left(\Sigma_{l=1}^{5} B_{t-l}^{H Y} / 5\right)\right]$ and $b_{t}^{I G}=\ln \left[\left(B_{t}^{I G}\right) /\left(\Sigma_{l=1}^{5} B_{t-l}^{I G} / 5\right)\right]$ where $B_{t}^{H Y}$ is the volume of high yield issuance in year $t$. Alternately, we can scale issuance by $G D P, \ln \left(B_{t}^{H Y} / G D P_{t}\right)$ and $\ln \left(B_{t}^{I G} / G D P_{t}\right)$. In horseraces between $b_{t}^{H Y}$ and $b_{t}^{I G}$ or $\ln \left(B_{t}^{H Y} / G D P_{t}\right)$ and $\ln \left(B_{t}^{I G} / G D P_{t}\right)$, low quality issuance is the strongest predictor.
} 
extend ISS ${ }^{E D F}$ back until 1952, obtaining similar results over this longer 57-year sample. The table also also suggest that the forecasting relationship has grown statistically and economically stronger in recent years.

We next add a number of additional control variables to our baseline forecasting regression. We first consider a variety of business-cycle controls. The most extreme of these tests is to include both lagged and future business cycle controls. ISS ${ }^{E D F}$ still retains its forecasting power, suggesting that its power does not derive - at least not exclusively - from its ability to predict future GDP or macro conditions. ${ }^{17}$ We also include the 8 principal components that Ludvigson and Ng (2010) extract from 130 macro variables. This has little impact on our results.

We next add several forecasting variables studied in the recent literature. Lettau and Ludvigson (2001) find that the consumption wealth ratio (cay) predicts stock market returns. Cochrane and Piazzesi (2005) show that a tent-shaped linear combination of forward interest rates forecasts the excess returns of long-term riskless bonds over short-term bonds. However, adding either variable as a control has almost no impact on the estimated coefficient on ISS ${ }^{E D F}$.

We then make various adjustments to the construction $I S S^{E D F}$ in equation (8). Using the raw level of $E D F$ rather than the $E D F$ decile strengthens our basic result in both univariate and multivariate specifications. We then examine the role of long-term versus short-term debt issuance (we follow Baker, Greenwood, and Wurgler (2003) in the computation of long-term and short-term debt issuance). These results suggest that the quality mix of long-term debt issuers is quite informative about returns, while the quality mix of short-term issuers is less so. This is to be expected given that major short-term debt issuers are almost always of exceptionally high credit quality. As mentioned above, we also obtain similar results if we compute the value weighted average EDF decile amongst high and low debt issuers (weighting by assets or total debt issued), or if we exclude financial firms. In summary, our results do not appear to be sensitive to variable construction.

One might wonder whether our results are sensitive to how we measure firm credit quality, namely using a Merton-style expected default frequency. For instance, Shumway (2001)

\footnotetext{
${ }^{17}$ Lown and Gertler (1999) and Stock and Watson (2003) find that high yield spreads forecast near-term GDP innovations.
} 
provides an empirical model of bankruptcy with higher predictive power than the Merton model. In row (18), we use Shumway's bankruptcy predictor (as opposed to EDF) in equation (8) and find that the resulting time-series, $I S S^{S H U M}$, is also a strong predictor of returns. In rows (19)(24), we perform a similar exercise with other measures of firm credit quality, in each case constructing ISS ${ }^{\text {Char }}$ so that high values indicate disproportionate issuance from lower credit quality firms. We examine interest coverage, leverage, stock return volatility, size, age, and payout policy. All of these measures line up in the right direction, and in 6 out of 7 cases, ISS Char is statistically significant.

The final four rows of Table 5 explore the link between $I S S^{E D F}$ and the equity market. We can control for contemporaneous equity returns (MKTRF), or, in the last line, for contemporaneous realizations of the three Fama-French (1993) factors, MKTRF, SMB, and HML. These controls do not meaningfully affect our results.

Last, our results are potentially subject to the econometric issues that arise in return forecasting regressions. In the Internet Appendix, we discuss these issues and conduct a number of time-series robustness checks. We consider alternate procedures for computing standard errors, including a moving-blocks bootstrap and parametric standard errors computed under the assumption that residuals follow an ARMA process. We also examine the possible impact of Stambaugh (1999) bias on our results. None of these adjustments alter our basic conclusions.

\section{E. Forecasting changes in credit spreads and future defaults}

Ideally, we would like to relate the initial quality of a cohort of bonds to holding period returns on that cohort. Such cohort-level information is not available, so we use the holding period return on bond indices composed of issues with a fixed credit rating. Excess returns on a portfolio of low grade bonds are a function of the initial spread, the subsequent change in spreads on non-defaulted bonds, and realized default and recovery rates: $r x_{t+1} \approx\left(1-D E F_{t+1}\right) \cdot\left[s_{t}-\operatorname{Dur} \cdot\left(s_{t+1}-s_{t}\right)\right]-D E F_{t+1} \cdot L G D_{t+1}$, where $D E F_{t+1}$ is the default rate, $S_{t}$ is the credit spread, Dur is bond duration, and $L G D_{t+1}$ is the loss-given-default. Table 6 shows that high values of $I S S^{E D F}$ forecast both future increases in credit spreads as well as high 
future default rates. Specifically, the left panel of Table 6 reports the results of regressions where we use $I S S^{E D F}$ to forecast cumulative changes in the Moody's BBB credit spread over the following 1-, 2-, and 3-year periods. ISS ${ }^{E D F}$ is a strong univariate forecaster of credit spread changes and remains significant in multivariate specifications that also control for the initial level of credit spreads. The right panel shows that $I S S^{E D F}$ is a reliable forecaster of future default rates on high yield bonds over the subsequent five years. Specifically, we use ISS ${ }^{E D F}$ to forecast the $k$-year ahead issuer-weighted default rate on high yield bonds from Moody’s Annual Default Survey, $D E F_{t+k}^{H Y}$ for $k=1$ to 3 .

\section{Discussion}

The previous section demonstrates that deteriorating debt issuer credit quality forecasts low excess returns on corporate bonds. This section evaluates potential explanations of the underlying variation in expected returns. We first consider explanations in which the quantity or rational price of risk varies over the credit cycle. Next, we discuss frictional explanations that emphasize shocks to intermediary capital or, alternately, time-varying agency problems. Finally, we examine explanations in which investor over-extrapolation plays a role.

\section{A. Time variation in the quantity of risk}

We first rule out explanations in which expected returns are mechanically linked to the composition of bonds in the high yield index. Specifically, the most natural arguments suggest that lower quality issuance should be associated with a larger quantity of risk, forecasting returns in the opposite direction of our findings. For instance, suppose the risk-premium on C-rated bonds is greater than that on B-rated bonds, which is greater than that on BB-rated bonds. This is what we might expect given that factor loadings on $M K T R F$ are largest for the lowest quality issues. Thus, a shift towards lower quality issuance should increase - not lower - the expected return on the high yield index as the average loadings on priced risk factors rise.

More generally, since the correlation between high yield excess returns and MKTRF may be time-varying, one might wonder if our results can be explained by a conditional-CAPM (e.g., high levels of ISS ${ }^{E D F}$ might signal low future loadings on stock market excess returns). However, 
we find that high values of $I S S^{E D F}$ are associated with higher, not lower, future loadings of $r x^{H Y}$ on stock market excess returns.

\section{B. Fluctuations in the rationally determined price of risk}

We now consider explanations in which time-variation in required returns is due to changes in the rationally determined price of risk. Countercyclical fluctuations in the price of risk arise in many consumption-based asset pricing models, such as those featuring habit formation (Campbell and Cochrane (1999)), time-varying consumption volatility (Bansal and Yaron (2004)), or time-varying consumption disaster risk (Barro (2006) and Gabaix (2010)). ${ }^{18}$ Under such explanations, a decline in investors' required returns during booms leads to a decline in issuer quality because changes in the price of risk have a greater impact on the investment (and hence debt issuance) decisions of low quality firms. ${ }^{19}$ Under such explanations, investors are not systematically surprised when the bonds of low quality firms who receive funding during booms later underperform.

Several of our findings are consistent with the idea that the rationally determined price of risk moves in a countercyclical fashion. Specifically, issuer quality has a clear business cycle component. In addition, adding macroeconomic controls often increases the $R^{2}$ in our forecasting regressions, while slightly reducing the magnitude of the coefficient on $I S S^{E D F}$. Our forecasting results are also strongest for lower-rated bonds, consistent with the idea that lower-rated bonds may be more highly exposed to consumption risk.

However, many of our findings are difficult to square with rational integrated-markets explanations. First, as previously shown in Table 5, the overall forecasting power of $I S S^{E D F}$ remains quite strong even if we control for macroeconomic variables. We may have overlooked some macroeconomic variables, but our results remain strong even after controlling for future realizations of macroeconomic variables, as well as the eight principal components Ludvigson

\footnotetext{
${ }^{18}$ Chen, Collin-Dufresne, and Goldstein (2009) argue that the habit formation models can explain the low level of defaults relative to the BBB-AAA spread if default losses are countercyclical. Bhamra, Kuehn, and Strebulaev (2008) and Chen (2009) combine consumption-based models in the long-run risks traditional with dynamic models of optimal capital structure.

${ }^{19}$ Suppose firms have access to projects that require an investment of $I$ at $t$, yield $E[C F]$ in expectation at $t+1$, and differ only in their risk exposure, $\beta_{i}$. Firm $i$ undertakes a bond offering and invests if $I \leq E[C F] / E_{t}\left[r x_{i, t+1}\right]$ or $\beta_{i} \leq \beta_{t}^{*}=E[C F] /\left(I \delta_{t}\right)$. The factor loading of the marginal issuing firm, $\beta_{t}^{*}$, and the average issuing firm, $E\left[\beta_{i} \mid \beta_{i} \leq \beta_{t-1}^{*}\right]$ are decreasing in $\delta_{t}$. According to this interpretation, changes in the price of risk affect the quality of the marginal firm that is investing and issuing debt.
} 
and Ng (2010) extract from 130 macroeconomic time series.

Second, we show that our measures of issuer quality forecast significantly negative excess returns on high yield bonds in a number of sample years. While consumption-based models with a rationally time-varying price of risk can explain periods in which high yield bonds command a larger or smaller risk premium, they would not generate negative risk premia. More formally, so long as the covariance of the stochastic discount factor with excess credit returns is negative - i.e., so long as credit assets are expected to underperform Treasuries during bad times, then consumption-based models would always generate positive expected excess returns for high yield bonds. This approach to testing asset pricing models avoids the joint hypothesis problem noted by Fama (1970) and has been used by Fama and Schwert (1977), Fama and French (1988), Kothari and Shanken (1997), and Baker and Wurgler (2000).

Specifically, each year we forecast $k$-period cumulative excess returns, compute the standard error of the fitted value, and count the number of years in which expected returns are negative with $95 \%$ confidence. $I S S^{E D F}$ has forecast significantly negative 3-year cumulative excess returns in 14 years since 1962, and all but one of these years was actually followed by negative excess returns. ISS ${ }^{E D F}$ has also forecast significantly negative excess returns at a 1-year and 2-year horizon in 7 and 14 sample years, respectively. We also find that ISS ${ }^{E D F}$ forecasts significantly negative excess returns on BBB bonds over 1- and 2-year horizons on five occasions, four of which were followed by negative excess returns. ${ }^{20}$ We can also estimate nonlinear forecasting models which nest the null that expected returns are always non-negative, enabling us to directly test this constraint. These tests are discussed in the Internet Appendix and indicate that the null of non-negative expected returns is strongly rejected by the data.

Third, the magnitude of the predictability we document is difficult to square with frictionless stories in which the price of risk varies over time. As discussed in Campbell and Thompson (2008) and Welch and Goyal (2008), it is useful to examine the out-of-sample

\footnotetext{
${ }^{20}$ We obtain similar results if we include higher powers of $I S S^{E D F}$ or if we include additional time-series controls. Another concern is that the average excess return of high yield bonds is fairly low in our sample. We can deal with this concern by setting a lower threshold. For instance, there are 12, 7, and 5 years in which the fitted 2-year excess return is significantly less than -1\%, $-2 \%$, and $-3 \%$, respectively. Alternately, we can work with simple excess returns, raising the average due to Jensen's inequality. Specifically, the average log excess return is $0.45 \%$ versus an average simple excess return of $1.15 \%$. However, if we work with simple excess returns, we predict significantly negative excess returns in almost the exact same number of years.
} 
forecasting power of a return predictor. Specifically, we compute out-of-sample $R^{2}$ using

$$
R_{O S}^{2}=1-\left(\sum_{t=s+1}^{T}\left(r x_{t}-\hat{r} x_{t}\right)^{2}\right) /\left(\sum_{t=s+1}^{T}\left(r x_{t}-\overline{r X}_{t}\right)^{2}\right)
$$

where $\hat{r} x_{t}$ is the fitted value from the forecasting regression estimated through time $t-1$ and $\overline{r x}_{t}$ is the average excess return estimated through $t-1 .^{21}$ We find large out-of-sample $R^{2}$ statistics: $R_{O S}^{2}=8.3 \%$ when using $I S S^{E D F}$ to forecast 1-year returns, $R_{O S}^{2}=16.9 \%$ for 2 -year returns, and $R_{O S}^{2}=10.5 \%$ for 3-year returns. As noted by Campbell and Thompson (2008), a large $R^{2}$ relative to an asset's Sharpe ratio implies large market-timing gains for mean-variance investors with stable preferences. The annual Sharpe-ratio of our high yield excess return series is 4\%, so an $R^{2}$ of $8 \%$ implies that a mean-variance investor could increase her expected excess return by a factor of 54 by observing $I S S^{E D F}{ }^{22}$ It is difficult to square the magnitude of such predictability with fully-rational stories, even ones with meaningful fluctuations in the price of risk.

Fourth, we showed in Table 5 that $I S S^{E D F}$ is largely disconnected from traditional predictors of the stock market. For instance, we obtain similar results controlling for the dividend yield or Lettau and Ludvigson's (2001) cay. Similarly, while $I S S^{E D F}$ is a reliable forecaster of excess credit returns, the Internet Appendix shows it has little ability to forecast stock market returns. However, we do find that $I S S^{E D F}$ has some ability to negatively forecast the Fama and French (1993) HML and SMB factors. Nonetheless, as previously shown in Table 5, the coefficient and significance of $I S S^{E D F}$ when forecasting high yield excess returns are largely unchanged even if we control for contemporaneous realizations of the Fama and French (1993) factors or the term premium. While this does not rule out all risk-based explanations, it suggests that issuer quality captures forces that are relatively specific to credit markets. This is consistent with Collin-Dufresne, Goldstein, and Martin (2001), who argue that credit spreads may be driven by localized supply and demand shocks.

\footnotetext{
${ }^{21}$ Following Campbell and Thompson (2008) and Welch and Goyal (2008), we use 20 years of data to fit our initial forecasting regression for annual returns from 1953 to 1972, so our first return forecast is for 1973.

${ }^{22}$ A mean-variance investor with risk aversion $\gamma$ earns an expected excess return of $\gamma^{-1} S^{2}$ where $S$ is the Sharpe ratio. However, an investor who observes the forecasting variable earns an average expected excess return of $\gamma^{-1}\left(S^{2}+R^{2}\right) /\left(1-R^{2}\right)$, so the percentage increase is $\left[R^{2} /\left(1-R^{2}\right)\right]\left[\left(1+S^{2}\right) / S^{2}\right]$. The magnitude of predictability we document for high yield bonds is generally greater than that found in the stock market, particularly in the post-war period. Specifically, an out-of-sample $R^{2}$ of $8 \%$ exceeds the statistics that Welch and Goyal (2008) obtain for univariate forecasts of annual stock returns. Similarly, Campbell and Thompson (2008) obtain out-of-sample $R^{2}$ statistics that are generally less than 5\% and never exceed $8 \%$.
} 


\section{Frictional explanations linked to intermediary balance sheets}

We next consider frictional explanations in which risk premia fluctuate due to the health of financial intermediary balance sheets. A growing literature argues that fluctuations in intermediary equity capital or balance sheet health impact risk premia. Interpreting this literature broadly, the mechanism is one in which intermediaries become more risk averse following shocks to their capital, which is only rebuilt gradually due to various frictions. ${ }^{23}$ These theories predict that ISS ${ }^{E D F}$ will be high when intermediary balance sheets are strong. Additionally, since intermediary capital is the driver of risk premia, these theories suggest that the coefficient on $I S S^{E D F}$ should be attenuated once we control for intermediary balance sheet strength.

Table 7 examines the relationship between ISS ${ }^{E D F}$ and the balance sheet strength of intermediaries. For each measure of financial intermediary health, $Z_{t}$, we first estimate its relationship with $I S S^{E D F}$

$$
I S S_{t}^{E D F}=a+b \cdot Z_{t}+c \cdot\left(y_{L, t}^{G}-y_{S, t}^{G}\right)+d \cdot y_{S, t}^{G}+e \cdot\left(y_{L, t}^{B B B}-y_{L, t}^{G}\right)+f \cdot r x_{t}^{H Y}+e_{t} \cdot
$$

We estimate (13) with and without the full suite of controls. These regressions are shown in the first two columns of Table 7. In the remaining four columns, we ask whether controlling for intermediary capital affects the ability of $I S S^{E D F}$ to forecast bond returns. Specifically, we estimate regressions of the form

$$
r x_{t+2}^{H Y}=a+b_{1} \cdot I S S_{t}^{E D F}+b_{2} \cdot Z_{t}+c \cdot\left(y_{L, t}^{G}-y_{S, t}^{G}\right)+d \cdot y_{S, t}^{G}+e \cdot\left(y_{L, t}^{B B B}-y_{L, t}^{G}\right)+f \cdot r x_{t}^{H Y}+u_{t+2},(1
$$

where $Z_{t}$ denotes balance sheet variables for different intermediary groups, including equity-toasset ratios $(E / A)$ and annual asset growth $(d A / A)$, are constructed from Flow of Funds data following Adrian, Moench, and Shin (2010).

Which intermediaries are relevant in the present context? We first consider insurers, which are the single largest group of corporate bond holders according to Flow of Funds data. As shown in the first two columns of Table 10, ISS ${ }^{E D F}$ tends to be high (i.e., issuer quality is low) when insurer equity-to-asset ratios are high as would be predicted by these theories. However, the remaining columns show that including measures of insurer balance sheet strength does not

\footnotetext{
${ }^{23}$ See, for example, Gromb and Vayanos (2002), Garleanu and Pedersen (2010), Duffie (2010), and He and Krishnamurthy (2010). Many accounts of the credit cycle also emphasize a role for fluctuations in bank balance sheets, including Holmstrom and Tirole (1997) and Kashyap, Stein, and Wilcox (1993).
} 
alter our forecasting results - neither the coefficient on $I S S^{E D F}$ nor its statistical significance is much changed by the additional controls.

We next consider broker-dealer balance sheets. While securities brokers are not major holders of corporate bonds, they serve as underwriters and provide liquidity in the over-thecounter secondary market for corporate bonds. Furthermore, Adrian, Moench, and Shin (2010) find that broker balance sheets contain useful information about a variety of risk premia. However, we do not find a strong relationship between broker-dealer balance sheets and ISS ${ }^{E D F}$.

Last, we consider three sets of proxies for the health of bank balance sheets: balance sheet variables ( $E / A$ and $d A / A)$, lagged bank stock returns, and bank loan loss provisions. Again, banks are not large holders of corporate bonds, but they are the main providers of corporate loans - the key substitute for bonds from firms' perspective. If a shortage of bank capital raises the returns banks require on loans, firms should substitute from loans to bonds until the expected returns on bonds and loans are equated. Thus, we might expect a negative shock to bank capital to raise the required returns on corporate bonds. Table 10 shows that lagged bank stock returns and bank loan loss provisions are correlated with $I S S^{E D F}$ in the expected direction. However, adding these controls hardly impacts the coefficient on $I S S^{E D F}$ in our forecasting regressions.

In summary, explanations involving limited intermediary capital go in the right direction, but do not appear to full explain the predictive power of $I S S^{E D F}{ }^{24}$ We also note that these explanations do not allow for negative expected excess returns, contrary to our findings.

\section{An agency-based explanation: "Reaching for yield"}

An alternate intermediary-related explanation is that time-varying risk premia are not driven by institutions' ability to take risk, but rather by their willingness to take risk due to agency problems. Rajan (2005) argues that certain institutional investors "reach for yield” when riskless interest rates are low or have recently fallen, hinting that the low flat yield curve of 2005-2006 may have led institutional investors to take on excessive risks. A number of observers

\footnotetext{
${ }^{24}$ The fact that issuer quality beats proxies for intermediary balance sheet strength in a horserace does not mean that fluctuations in intermediary risk tolerance are unimportant. As discussed above, issuer quality is an equilibrium outcome that may function as a sufficient statistic for a number of primitive forces, including the health of intermediary balance sheets, which drive risk premia in credit markets. And, if a large number of primitive factors drive risk premia, we might expect issuer quality to win head-tohead horseraces against proxies for each of those individual factors.
} 
have pointed to the low level of nominal rates as a key driver of the surge in high yield issuance in 2010. Similarly, Klarman (1991) argues that one impetus to the 1980s junk bond boom was from investors eager to earn the same high nominal returns they had earned in the early 1980s.

There are numerous forces encouraging intermediaries to reach for yield. A first is that low interest rates make intermediaries with fixed liabilities - such as life insurers - willing to take on more asset risk. When interest rates are high these intermediaries can meet fixed obligations without taking on significant risk. By contrast, low interest rates create the equivalent of a debt overhang problem and lead managers to engage in risk-shifting (Jensen and Meckling (1976)), accepting greater risk in exchange for lower expected returns. A second force stems from the incentives facing investment managers who are compensated based on nominal absolute returns, which may also encourage risk-shifting when interest rates are low. These agency-based explanations do not require mistaken beliefs on the part of investment managers, who are assumed to respond optimally to incentives. Furthermore, these explanations are also potentially consistent with negative expected returns.

Further evidence on the reaching for yield hypothesis is shown in Table 8 which explores the time-series determinants of issuer quality from 1962-2008. We regress the level of $I S S^{E D F}$ on interest rates, the term spread, past high yield default rates, and past high yield excess returns

$$
I S S_{t}^{E D F}=a+b \cdot y_{S, t}^{G}+c \cdot\left(y_{L, t}^{G}-y_{S, t}^{G}\right)+d \cdot r x_{t-1}^{H Y}+e \cdot D E F_{t}^{H Y}+u_{t} .
$$

We also run this regression in changes

$$
\Delta_{k} I S S_{t}^{E D F}=a+b \cdot \Delta_{k} y_{S, t}^{G}+c \cdot \Delta_{k}\left(y_{L, t}^{G}-y_{S, t}^{G}\right)+d \cdot r x_{t-k-1 \rightarrow t-1}^{H Y}+e \cdot \Delta_{k} D E F_{t}^{H Y}+\Delta_{k} u_{t},
$$

where $\Delta_{k}$ denotes the $k$-year difference and $r x_{t-k-1 \rightarrow t-1}^{H Y}$ denotes the excess high yield return between $t-k$ and $t-1$. Consistent with the reaching for yield hypothesis, ISS ${ }^{E D F}$ rises when interest rates or the term spread are low, or have recently fallen. Column (1) shows that the term spread and T-bill yield alone capture $44 \%$ (or $36 \%$ when looked at in changes) of the variation in $I S S^{E D F}$. However, reaching for yield appears unlikely to be the whole story, since, as shown in Table 3, interest rate controls do not affect our basic forecasting regressions.

To summarize, both consumption-based explanations that emphasize rationally time- 
varying discount rates, as well as frictional explanations that are based on limited intermediary capital or agency problems have some ability to explain certain aspects of our findings. However, the forecasting power of issuer quality is robust to a variety of controls suggested by these theories. Given this, it is tempting to simply attribute the residual to some unspecified form of mispricing. Below, we take a different route, articulating one a specific account of mispricing that relies on over-extrapolation.

\section{E. Investor over-extrapolation and mispricing}

Finally, we consider explanations in which biased investor beliefs generate predictable variation in excess corporate bond returns. A natural story is that investors over-extrapolate past defaults or past volatility realizations, leading to time-varying mispricing of corporate bonds. For instance, following a period of low defaults, investors may begin to believe that low credit quality firms are safer than they truly are, leading them to bid up the prices of risky debt. Recognizing that credit is cheap, low quality firms would then issue large amounts of debt,

making them even more likely to default in the future. As a result, issuer quality would negatively forecast excess corporate bond returns.

While extrapolative expectations deviate from the rational ideal, they may not be unrealistic. Researchers have shown that subjects are prone to over-extrapolation in a wide variety of settings. Specifically, subjects often use a "representativeness" heuristic, drawing strong conclusions from small samples of data (Tversky and Kahneman (1974)). We also note that many intermediaries use backward-looking risk management systems such as Value-at-Risk when extending credit. These systems may result in over-extrapolation, leading financial institutions to under-estimate future risks following periods of low volatility or low credit losses.

A more formal account of over-extrapolation in credit markets might go as follows. (The details of such a model are provided in the Internet Appendix.) Suppose the economy exogenously switches between good times in which few firms default, and bad times in which a higher fraction of firms default. However, following Barberis, Shleifer, and Vishny (1998), investors think that the economy either evolves according to a more or less persistent process. Following a string of low-default realizations, investors start to believe that the process 
governing defaults is more persistent than it truly is, leading them to under-estimate future default probabilities and bid up the price of risky corporate debt. These expectations will be revised after a period of high corporate defaults, resulting in a sharp decline in bond prices. If these bad times persist for long enough, investors will begin to over-estimate future default probabilities. According to this interpretation, credit market "sentiment" is favorable (unfavorable) when investors are underestimating (overestimating) future default probabilities. These dynamics generate short-term return continuation and longer-term return reversals for corporate bonds.

To understand why the quality of corporate debt issuance might contain information about future bond returns, consider how firms would behave in this environment. Low quality firms would respond by issuing overpriced debt during booms, raising their leverage. Although investors know that leverage impacts default probabilities, their growing belief that good times are likely to persist leads them to underestimate the impact of rising leverage on default probabilities. Following a string of low aggregate defaults, investors become willing to lend to more highly levered firms for a given spread. Thus, a lower level of issuer quality is associated with greater over-optimism about future default rates and lower expected returns.

There are two reasons to take seriously an explanation in which investors make expectational errors. First, it is consistent with the finding that expected excess returns may sometimes be negative. Second, a distinguishing prediction is that issuer quality should be low following a string of low realized defaults. The results in Table 8 bear this out. Specifically, $I S S^{E D F}$ is high (i.e., issuer quality is low) following periods when default rates have been low and high yield excess returns have been high. These patterns are particularly pronounced when analyzed in changes: past defaults and returns explain $65 \%$ of the 2 -year changes in ISS ${ }^{E D F}$. Furthermore, these results continue to hold even if we control for recent macroeconomic conditions or recent stock returns. Thus, Table 8 suggests that the recent experience of credit market investors may play an important role in shaping their current expectations.

Consistent with the idea that the extrapolation of past performance can explain much of the time-variation in issuer quality, we obtain similar return forecasting results if we instrument 
for ISS ${ }^{E D F}$ using past high yield default rates. Specifically, estimating $r x_{t+2}^{H Y}=a+b \cdot I S S_{t}^{E D F}+u_{t+2}$ using 2SLS yields $b=-18.503(t=-4.93)$ versus an OLS estimate of $b=-15.254(t=-5.29)$.

\section{Conclusions}

In the wake of the 2008-2009 financial crisis, a number of authors have argued that credit booms and busts can have important consequences for real economic activity (e.g., Ivashina and Scharfstein (2009) and Blinder (2010)). Since debt comprises the vast majority of external corporate finance, it is surprising that little effort has been devoted to connect these booms and busts to investor beliefs or tastes. For example, a large literature in corporate finance and macroeconomics identifies reasons why the quantity of credit may fluctuate over the business cycle, but makes little attempt to connect these changes to investor returns.

Our main contribution is to construct a comprehensive measure of issuer quality and to use this measure to forecast excess corporate bond returns. When issuer quality is low, corporate bonds subsequently underperform Treasuries. We uncover a striking degree of predictability and often forecast significantly negative excess returns. These results are difficult to fully explain using rationally time-varying risk aversion or other drivers of countercyclical risk premia. Instead, the findings suggest that it is worthwhile to consider explanations in which intermediary frictions drive variation in required returns, or explanations in which investors may systematically err in assessing credit quality at different stages of the credit cycle.

The results in this paper have implications for the ongoing debate about whether central banks should lean against incipient credit booms. For instance, the Basel Commmitee (2010) has proposed varying bank capital buffers over the cycle to protect the banking sector against periods of "excess aggregate credit growth.” A major challenge for any policy of this sort is identifying the existence of a credit boom in the first place. Our results suggest that looking at credit quantities alone may not be enough - we may also want to consider the credit quality of debt market financing. 


\section{References}

Adrian, Tobias, Emmanuel Moench, and Hyun Song Shin, 2010, Macro Risk Premium and Intermediary Balance Sheet Quantities, IMF Economic Review, forthcoming.

Asquith, Paul, David Mullins, and Eric Wolff, 1989, Original Issue High Yield Bonds: Aging Analyses of Defaults, Exchanges, and Calls, Journal of Finance 44, 923-952.

Atkinson, Thomas R., 1967, Trends in Corporate Bond Quality, Columbia University Press, New York.

Axelson, Ulf, Tim Jenkinson, Per Stromberg, and Michael S. Weisbach, 2010, Leverage and Pricing in Buyouts: An Empirical Analysis, Journal of Finance forthcoming.

Baghai, Ramin, Henri Servaes, and Ane Tamayo, 2010, Have Rating Agencies Become More Conservative?, London Business School Working Paper.

Baker, Malcolm, Robin Greenwood, and Jeffrey Wurgler, 2003, The Maturity of Debt Issues and Predictable Variation in Bond Returns, Journal of Financial Economics 70, 261-291.

Baker, Malcolm, and Jeffrey Wurgler, 2000, The Equity Share in New Issues and Aggregate Stock Returns, Journal of Finance 55, 2219-2257.

Bansal, Ravi and Amir Yaron, 2004, Risks for the Long Run: A Potential Resolution of Asset Pricing Puzzles, Journal of Finance 59, 1481-1509.

Barberis, Nicholas, Andrei Shleifer, and Robert Vishny, 1998, A Model of Investor Sentiment, Journal of Financial Economics 49, 307-343.

Barro, Robert J., 2006, Rare Events and the Equity Premium, Quarterly Journal of Economics

Basel Committee on Banking Supervision, 2010, “The Basel Committee's Response to the Financial Crisis: Report to the G20,” <http://www.bis.org/publ/bcbs179.pdf>

Becker, Bo and Victoria Ivashina, 2010, Cyclicality of Credit Supply: Firm Level Evidence, Harvard Business School Working Paper 10-107.

Bernanke, Ben and Mark Gertler, 1989, Agency Costs, Net Worth, and Business Fluctuations, American Economic Review 79, 14-31.

Bernanke, Ben, Mark Gertler, and Simon Gilchrist, 1996, The Financial Accelerator and the Flight to Quality, The Review of Economics and Statistics 78, 1-15.

Bhamra, Harjoat S., Lars-Alexander Kuehn, and Ilya A. Strebulaev, 2008, The Aggregate Dynamics of Capital Structure and Macroeconomic Risk, Standard University Working Paper.

Bharath, Sreedhar T., and Tyler Shumway, 2008, Forecasting Default with the Merton Distance to Default Model, Review of Financial Studies 21, 1339-1369.

Blinder, Alan, 2010, The Squam Lake Report: Fifteen Economists in Search of Financial Reform, forthcoming Journal of Monetary Economics, 57(7).

Blume, Marshall E., Felix Lim, and A. Craig MacKinlay, 1998. The Declining Credit Quality of 
U.S. Corporate Debt: Myth or Reality? Journal of Finance 53, 1389-1413.

Campbell, John Y., and John H. Cochrane, 1999, By Force of Habit: A Consumption-based Explanation of Aggregate Stock Market Behavior, Journal of Political Economy 107, 205-251.

Campbell, John Y., and Samuel B. Thompson, 2008, Predicting Excess Stock Returns Out of Sample: Can anything beat the historical average?, Review of Financial Studies 21, 15091531.

Chen, Hui, 2009, Macroeconomic Conditions and the Puzzles of Credit Spreads and Capital Structure, Journal of Finance, forthcoming.

Chen, Long, Pierre Collin-Dufresne, and Robert S. Goldstein, 2009, On the Relation between the Credit Spread Puzzle and the Equity Premium Puzzle, Review of Financial Studies 22, 3367-3409

Cochrane, John, and Monika Piazzesi, 2005, Bond Risk Premia, American Economic Review 95, 138-160.

Collin-Dufresne, Pierre, Robert S. Goldstein, and J. Spencer Martin, 2001. The Determinants of Credit Spread Changes, Journal of Finance 56, 2177-2207.

Coval, Joshua D., Jakub W. Jurek, and Erik Stafford, 2009, Economic Catastrophe Bonds. American Economic Review 99, 628-666.

Duffie, Darrell, 2010, Asset Price Dynamics with Slow-Moving Capital, Journal of Finance 65: 1238-1268.

Duffie, Darrell, and John Singleton, 1999, Modeling Term Structures of Defaultable Bonds, Review of Financial Studies 12, 687-720.

Fama, Eugene F., 1970, Efficient Capital Markets: A Review of Theory and Empirical Work, Journal of Finance 25, 383-417.

Fama, Eugene F., and Kenneth R. French, 1988, Dividend Yields and Expected Stock Returns, Journal of Financial Economics 22, 3-25.

Fama, Eugene F. and Kenneth R. French, 1989, Business Conditions and Expected Returns on Stocks and Bonds, Journal of Financial Economics 25:23-50.

Fama, Eugene F. and Kenneth R. French, 1993, Common risk factors in the returns on stocks and bonds, Journal of Financial Economics 33, 3-56.

Fama, Eugene F. and Kenneth R. French, 2008, Dissecting Anomalies, Journal of Finance 63, 1653-1678.

Fama, Eugene F., and G. William Schwert, 1977, Asset Returns and Inflation, Journal of Financial Economics 5, 115-146.

Gabaix, Xavier, 2010, Variable Rare Disasters: An Exactly Solved Framework for Ten Puzzles in Macro-Finance, Quarterly Journal of Economics forthcoming.

Garleanu, Nicolae and Lasse Heje Pedersen, 2010, Margin-Based Asset Pricing and Deviations 
from the Law of One Price, New York University Working Paper.

Gertler, Mark and Cara Lown, 1999, The Information Content of the High Yield Bond Spread for the Business Cycle, Oxford Review of Economic Policy 15, 132-150.

Grant, James, 1992, Money of the Mind, Farrar, Straus and Giroux, New York.

Greenwood, Robin, and Samuel Hanson, 2011, Share Issuance and Factor Timing, forthcoming Journal of Finance.

Greenwood, Robin, Samuel Hanson, and Jeremy C. Stein, 2010, A Gap-Filling Theory of Corporate Debt Maturity Choice, Journal of Finance 65, 993-1028.

Gromb, Denis, and Dimitri Vayanos, 2002, Equilibrium and Welfare in Markets with Constrained Arbitrageurs” Journal of Financial Economics 66, 361-407.

He, Zhiguo and Arvind Krishnamurthy, 2010, Intermediary Asset Pricing, Working Paper.

Hickman, W. Braddock, 1958, Corporate Bond Quality and Investor Experience, Princeton University Press, Princeton.

Hickman, W. Braddock, 1960, Statistical Measures of Corporate Bond Financing Since 1900, UMI.

Hodrick, Robert, and Edward C. Prescott, 1997, Postwar U.S. Business Cycles: An Empirical Investigation, Journal of Money, Credit, and Banking, 1-16.

Holmstrom, Bengt and Jean Tirole, 1997,Financial Intermediation, Loanable Funds and the Real Sector, Quarterly Journal of Economics, 112, 663-691

Ivashina, Victoria, and David Scharfstein, 2009, Bank Lending in the Financial Crisis of 2008, Journal of Financial Economics

Ivashina, Victoria, and Zheng Sun, 2010, Institutional Demand Pressure and the Cost of Corporate Loans, Journal of Financial Economics forthcoming.

Jensen, Michael C. and William H. Meckling, 1976, Theory of the Firm: Managerial Behavior, Agency Costs and Ownership Structure, Journal of Financial Economics 3: 305-360.

Kaplan, Steven N. and Jeremy C. Stein, 1993. The Evolution of Pricing and Financial Structure in the 1980s, The Quarterly Journal of Economics 108, 313-357.

Kashyap, Anil K, Jeremy C Stein, and David W. Wilcox, 1993. Monetary Policy and Credit Conditions: Evidence from the Composition of External Finance, American Economic Review 83, 78-98.

Keim, Donald B. and Robert F. Stambaugh, 1986, Predicting Returns in the Stock and Bond Markets, Journal of Financial Economics 17, 357-390.

Kiyotaki, Nobuhiro and John Moore, 1997, Credit Cycles, Journal of Political Economy 105, 211-248.

Klarman, Seth, 1991, Margin of Safety: Risk-Averse Value Investing Strategies for the Thoughtful Investor, Harper Collins, New York. 
Kothari, S. P., and Jay Shanken, 1997, Book-to-market, Dividend Yield, and Expected Market Returns: A Time-series Analysis, Journal of Financial Economics 44, 169-203

Krishnamurthy, Arvind, and Annette Vissing-Jorgensen, 2010, The Aggregate Demand for Treasury Debt, Northwestern University Working Paper.

Lettau, Martin and Sydney Ludvigson, 2001, Resurrecting the (C)CAPM: A Cross-Sectional Test When Risk Premia are Time-Varying. Journal of Political Economy 109, 12381287.

Loughran, Tim, and Jay R. Ritter, 1995, The New Issues Puzzle, Journal of Finance 50, 23 - 51.

Lown, Cara and Donald P. Morgan., 2006, The Credit Cycle and the Business Cycle: New Findings Using the Loan Officer Opinion Survey, Journal of Money, Credit and Banking 38, 1575-97.

Ludvigson, Sydney, and Serena Ng, 2010, A Factor Analysis of Bond Risk Premia, Handbook of Applied Econometrics, forthcoming.

Merton, Robert C., 1974, On the Pricing of Corporate Debt: The Risk Structure of Interest Rates, Journal of Finance 29, 449-470.

Newey, Whitney K., and Kenneth D. West, 1987, A Simple, Positive Semi-Definite, Heteroskedasticity and Autocorrelation Consistent Covariance Matrix, Econometrica 55, 703-708.

Rajan, Raghuram, 2005, Has Financial Development Made the World Riskier?, Jackson Hole Economic Symposium Proceedings, Federal Reserve Bank of Kansas City, 313-369.

Shivdasani, Anil and Yihui Wang, 2009, Did Structured Credit Fuel the LBO Boom? University of North Carolina Working Paper.

Shleifer, Andrei, and Robert Vishny, 1997, The Limits of Arbitrage, Journal of Finance 35-55.

Shumway, Tyler, 2001, Forecasting Bankruptcy More Accurately: A Simple Hazard Model, Journal of Business 74, 101-124.

Stambaugh, Robert F., 1999, Predictive Regressions, Journal of Financial Economics 54, 375421.

Stein, Jeremy C., 1996, Rational Capital Budgeting in an Irrational World, Journal of Business 69, 429 - 455.

Stock, James H. and Mark W. Watson, 2003, Has the Business Cycle Changed and Why? NBER Macroeconomics Annual 2002, 17, 159-230.

Tversky, Amos., and Daniel Kahneman, 1974. Judgment Under Uncertainty: Heuristics and Biases, Science 185, 1124-1131.

Welch, Ivo, and Amit Goyal, 2008, A Comprehensive Look at The Empirical Performance of Equity Premium Prediction, Review of Financial Studies 21, 1455-1508. 


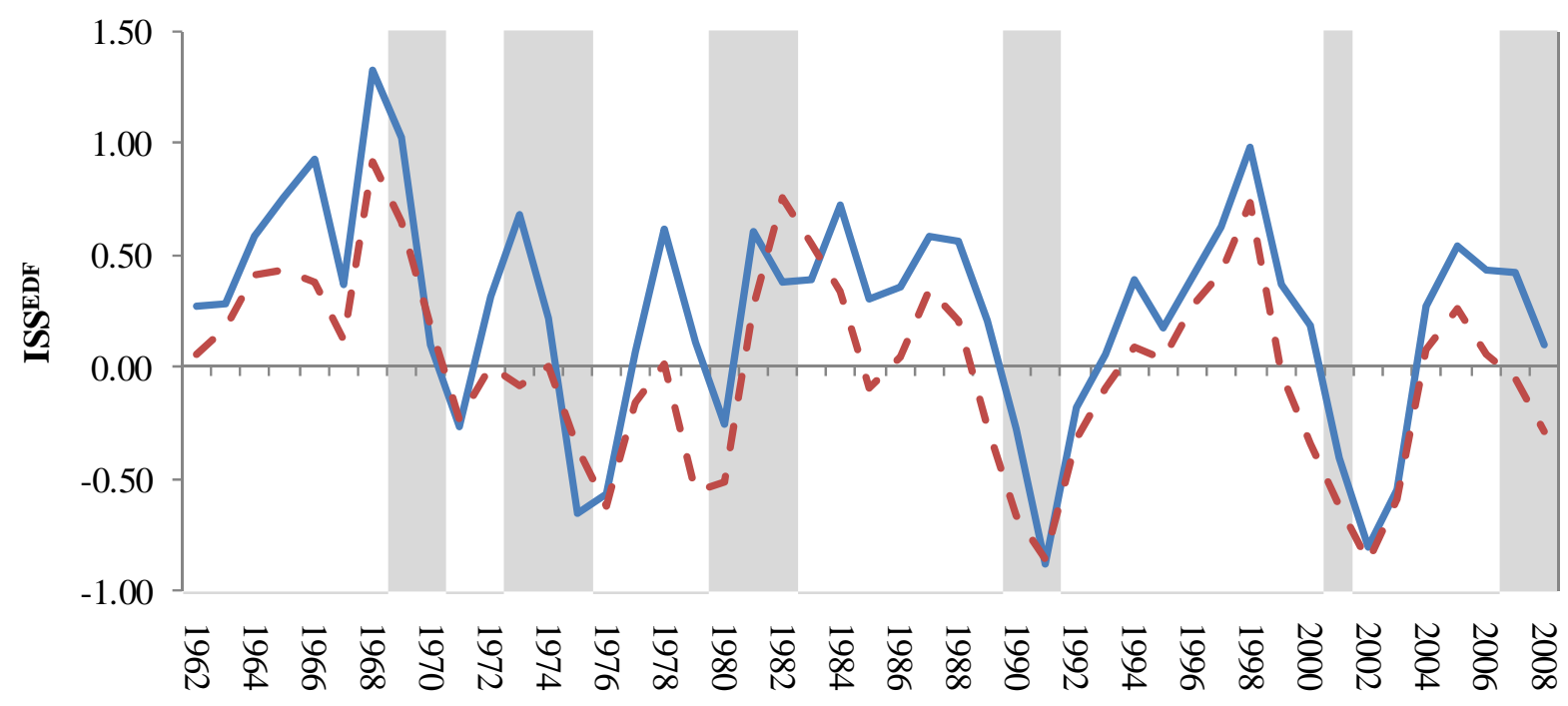

\section{Recession — ISS EDF - - ISS EDF (Orthogonalized to Macro variables)}

Figure 1. Issuer Quality. ISS ${ }^{E D F}$, is the difference between the average $E D F$ decile between high and low debt issuers. $E D F$ is the expected default frequency of Merton (1974). The figure also shows shading for NBER-designated recessions. The dotted line shows a version of $I S S^{E D F}$ that has been orthogonalized with respect to the output gap (Hodrick-Prescott filtered real GDP).

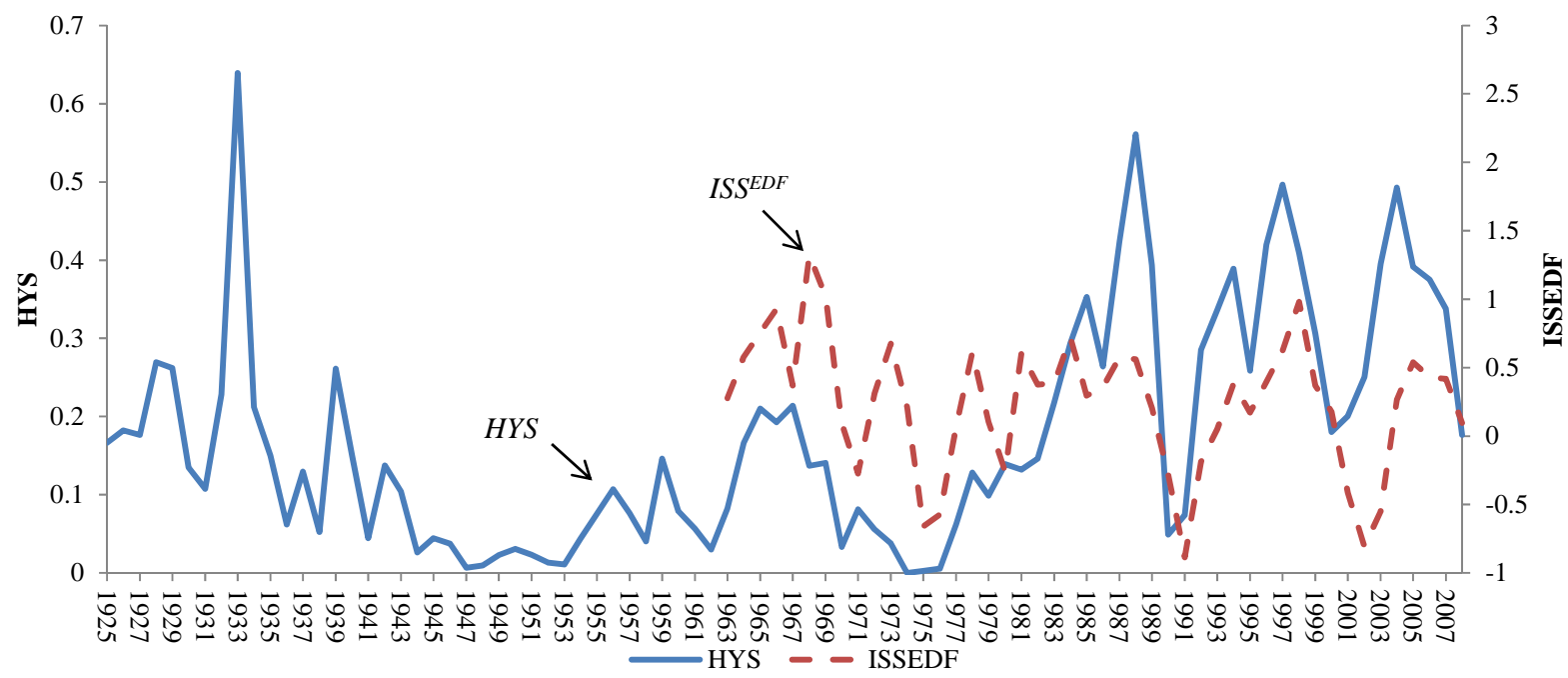

Figure 2. The High Yield Share. HYS is the log fraction of non-financial corporate bond issuance with a high yield rating from Moody's. HYS is constructed using data from Hickman (1960) and Atkinson's (1967) NBER studies from 1926-1965, from handcollected data from Moody's Bond Survey's from 1966-1982, and from FISD for 1983-2008. For comparison, the figure plots $I S S^{E D F}$ on the right-scale. 


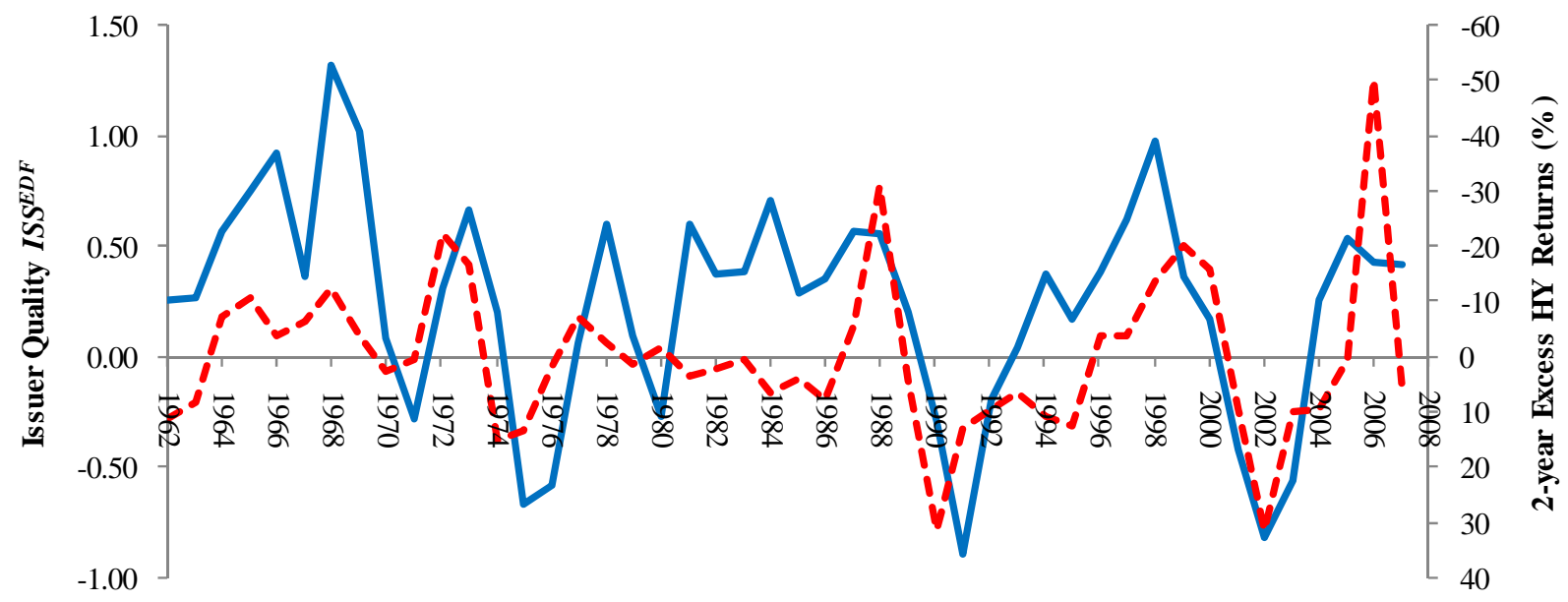

ISS EDF - - - 2--year Excess High Yield Returns (\%)

Figure 3. Issuer Quality and Subsequent High Yield Excess Returns. Issuer quality (left axis) plotted alongside cumulative excess high yield bond returns for the following two years (right axis). Returns are plotted in reverse scale, so the negative correlation appears positive visually. Issuer quality is measured with $I S S^{E D F}$, the difference between the average $E D F$ decile of high and low debt issuers from 1962- 2008.

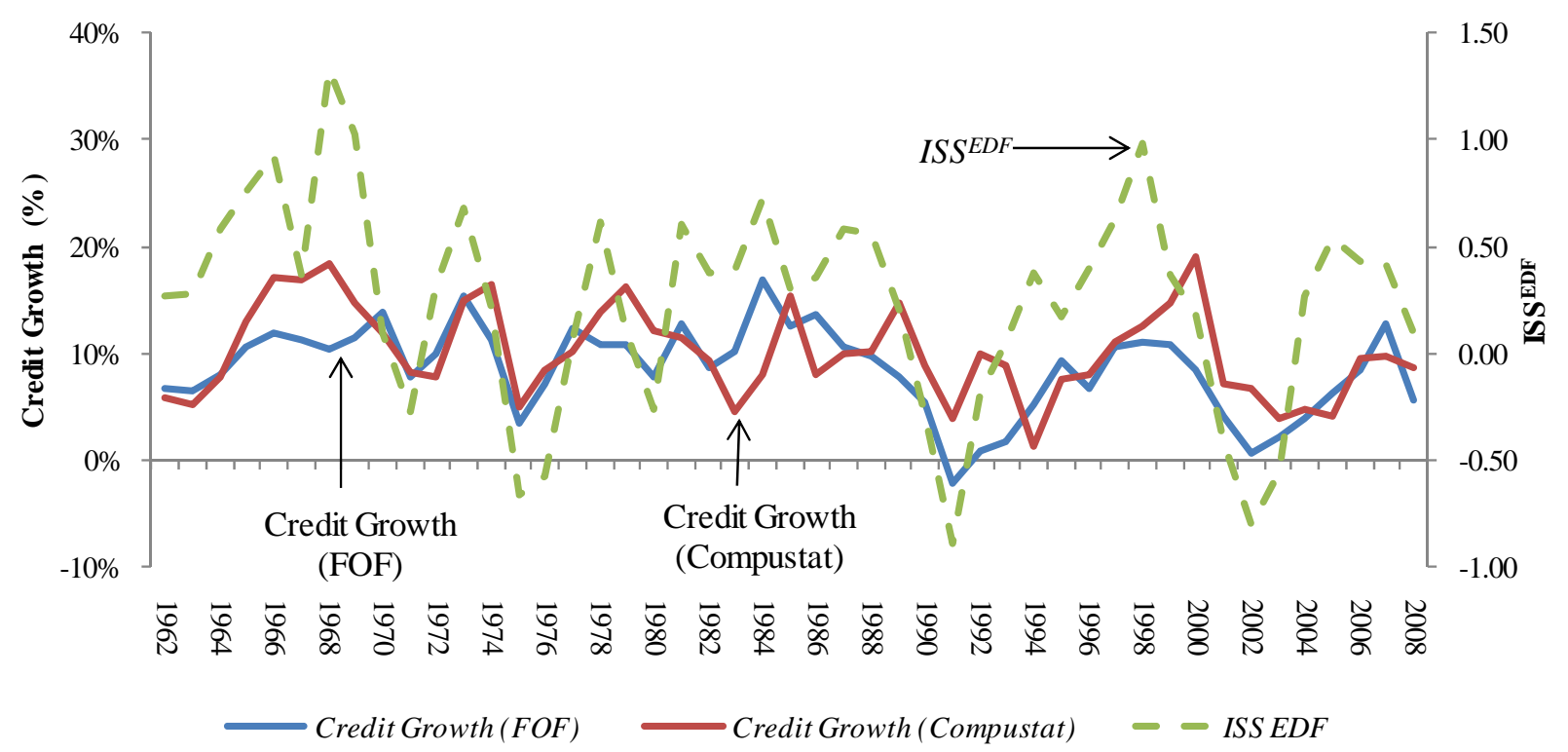

Figure 4. Quality and Quantity and the Credit Cycle. The figure plots the Flow of Funds (FOF) and Compustat-based measures of aggregate non-financial credit growth on the left axis versus our measures of issuer quality, ISS ${ }^{E D F}$, on the right-axis. 
Table 1

\section{Summary Statistics}

Mean, median, standard deviation, and extreme values of firm characteristics (Panel A) and time-series variables (Panels B-E). Panel A summarizes the firm-level characteristics, with the exact details of their construction given in the Internet Appendix. Net debt issuance is the change in assets minus the change in book equity, scaled by by lagged assets. Net equity issuance is the growth of balance sheet equity, net of retained earnings, scaled by lagged assets. External finance is the sum of net debt and net equity issuance. EDF is the Merton (1974) expected default frequency, calculated following Bharath and Shumway (2008). SHUM is the bankruptcy hazard rate as estimated by Shumway (2001). Interest coverage is EBITDA divided by annual interest expense. Leverage is book debt over assets. Age is the number of years on CRSP. Dividends is annual cash dividend scaled by assets. For each characteristic $X$, ISS ${ }^{X}$ compares the $^{2}$ average characteristic decile of high and low quintile debt issuers in that year, where quintiles are based on NYSE breakpoints. These time-series are summarized in Panel B. Characteristics include EDF, SHUM, interest coverage, leverage, idiosyncratic volatility, size, age, and dividend policy. "High" and "Low" are defined such that high is associated with a higher default probabilities. Panel C summarizes the high yield share HYS, which is the dollar fraction of non-financial debt issues receive a high yield rating, according to Moody's. From 1983-2008, HYS is based on data from the Fixed Income Securities Database (FISD). HYS from 1966-1982 is based on our assembly of bond issues from the Moody's Bond Surveys, HYS from 1944-1965 is based on Table B-1 of Atkinson (1967), and HYS from 1926-1943 is based on Table 52 of Hickman (1960). Panel D summarizes bond returns and the time-series control variables. $y_{S}$ the log yield on the short-term government bond. $y_{G L}-y_{G S}$ is the spread between the yields on the intermediate- and short-term government bonds from Ibbotson, and $y_{B B B}-y_{G L}$ is the BBB credit spread. Growth in industrial production, aggregate consumption growth, a recession dummy, the output gap, and Lettau and Ludvigson's (2001) consumption wealth ratio (cay) are macroeconomic control variables. Log excess returns on corporate bonds are computed for bond index returns based on high yield (HY), BBB-rated, and AAArated bonds, and are denoted $r x$. Excess stock returns (MKTRF), HML returns, and SMB are from Ken French. Panel E summarizes timeseries measures of intermediary balance sheet strength, including bank balance sheet capital (total assets minus liabilities all over assets) and bank balance sheet growth (percentage change in total assets); insurer balance sheet capital (total assets minus liabilities all over assets) and insurer balance sheet growth (percentage change in total assets); broker dealer balance sheet capital (total assets minus liabilities all over assets) and balance sheet growth (percentage change in total assets); lagged equal weighted returns on bank stocks based on Fama and French 48-industry classifications; and bank loan loss provisions scaled by total loans and leases from Table CB11 from the FDIC's Historical Statistics on Banking. Bank, Insurer, and Broker Dealer data are from the Flow of Funds accounts. Banks include commercial banks (Table L109), saving institutions (L114) and credit unions (L115). Insurance companies include property and casualty (Table L116) and life (Table L117). Broker dealers are on Table L129.

\begin{tabular}{|c|c|c|c|c|c|}
\hline & Mean & Median & SD & Min & Max \\
\hline \multicolumn{6}{|c|}{ Panel A: Firm-level data (1962-2008, firm-year observations) } \\
\hline Debt issues: $d / A$ & 0.09 & 0.04 & 0.40 & -4.13 & 6.50 \\
\hline Equity issues: $e / A$ & 0.24 & 0.01 & 1.54 & -0.55 & 48.09 \\
\hline External Finance: $(d+e) / A$ & 0.30 & 0.09 & 1.31 & -0.75 & 40.96 \\
\hline Expected Default Frequency: EDF & 0.06 & 0.00 & 0.18 & 0.00 & 1.00 \\
\hline Shumway Distress: SHUM & 0.02 & 0.00 & 0.07 & 0.00 & 0.97 \\
\hline Interest coverage: $i / E B I T D A$ & 23.72 & 5.44 & 223.97 & -3976.00 & $5,779.57$ \\
\hline Leverage: $D / A$ & 0.23 & 0.20 & 0.19 & 0.00 & 0.85 \\
\hline Market Capitalization: $\log (M V)$ & $1,166.39$ & 75.62 & $8,367.79$ & 0.11 & $60,2432.90$ \\
\hline Age & 13.25 & 8.42 & 14.17 & 0.00 & 83.00 \\
\hline Dividends & 0.02 & 0.00 & 0.03 & 0.00 & 0.60 \\
\hline \multicolumn{6}{|c|}{ Panel B: Debt issuer quality (1962-2008, annual time series) } \\
\hline$I S^{E D F}$ Expected Default Frequency (high-low) & 0.25 & 0.31 & 0.48 & -0.88 & 1.32 \\
\hline ISS ${ }^{\text {Shum }}$ Shumway distress (high-low) & 0.11 & 0.14 & 0.32 & -0.79 & 0.78 \\
\hline ISS $^{\text {Intcov }}$ Interest coverage (low-high) & -0.22 & -0.24 & 0.39 & -0.98 & 0.81 \\
\hline ISS ${ }^{\text {Lev }}$ Leverage (low-high) & 1.23 & 1.24 & 0.57 & -0.03 & 2.58 \\
\hline ISS $^{\sigma}$ CAPM $\sigma$ (low-high) & -0.35 & -0.30 & 0.54 & -1.66 & 0.89 \\
\hline$I_{S S^{M E}}$ Size (small-large) & -0.60 & -0.60 & 0.29 & -1.24 & 0.04 \\
\hline ISS ${ }^{A g e}$ Age (young-old) & 0.59 & 0.58 & 0.24 & -0.09 & 1.06 \\
\hline ISS $^{\text {Nonpayer }}$ Dividends (nonpayer-payer) & -0.06 & -0.05 & 0.06 & -0.20 & 0.08 \\
\hline \multicolumn{6}{|c|}{ Panel C: The High Yield Share (1926-2008, annual time series) } \\
\hline HYS (FISD, 1983-2008) & 0.32 & 0.34 & 0.12 & 0.05 & 0.56 \\
\hline HYS (Moodys manuals \& NBER, 1926-1982) & 0.11 & 0.08 & 0.10 & 0.00 & 0.64 \\
\hline HYS (Spliced series, 1926-2008) & 0.18 & 0.14 & 0.15 & 0.00 & 0.64 \\
\hline
\end{tabular}


Table 1 (Continued)

Summary Statistics

\begin{tabular}{|c|c|c|c|c|c|}
\hline & Mean & Median & SD & Min & Max \\
\hline \multicolumn{6}{|c|}{ Panel D: Returns and macroeconomic controls \% (1962-2008, annual time series) } \\
\hline \multicolumn{6}{|c|}{ Macroeconomic Controls: } \\
\hline$y_{S, t}^{G}$ & 5.61 & 5.23 & 3.12 & 0.03 & 16.86 \\
\hline$y_{L t}^{G}-y_{S . t}^{G}$ & 0.37 & 0.37 & 0.84 & -1.73 & 2.28 \\
\hline$y_{t}^{B B B}-y_{L t}^{G}$ & 1.69 & 1.60 & 0.77 & 0.50 & 5.11 \\
\hline Industrial Production & 2.76 & 3.06 & 4.38 & -9.74 & 9.52 \\
\hline Aggregate Consumption Growth & 3.36 & 3.46 & 1.81 & -1.21 & 6.13 \\
\hline Recession Dummy & 0.29 & 0.00 & 0.46 & 0.00 & 1.00 \\
\hline Output Gap (HP filtered log GDP) & 0.02 & 0.08 & 1.37 & -3.68 & 3.09 \\
\hline Cay & -0.01 & 0.01 & 1.52 & -3.52 & 3.28 \\
\hline$F_{1}(1964-2007)$ & -6.21 & -21.15 & 120.66 & -198.90 & 490.20 \\
\hline$F_{2}(1964-2007)$ & 12.55 & 23.84 & 113.24 & -361.34 & 268.16 \\
\hline$F_{3}(1964-2007)$ & -12.57 & -17.88 & 91.49 & -373.68 & 250.01 \\
\hline \multicolumn{6}{|l|}{ Returns: } \\
\hline$r x^{H Y}{ }_{t+1}$ (1-year excess High Yield return) & 0.45 & 1.98 & 13.10 & -42.65 & 48.31 \\
\hline$r x_{t+1}^{B B B}(1$-year excess BBB return) & 0.53 & 0.64 & 7.02 & -22.42 & 27.91 \\
\hline$r x_{t+1}^{A A A}(1$-year excess AAA return) & -0.51 & 0.39 & 3.40 & -8.44 & 4.22 \\
\hline$r x^{H Y}{ }_{t+2}$ (2-year excess High Yield return) & -0.23 & 1.42 & 14.34 & -50.37 & 31.38 \\
\hline$r x_{t+2}^{B B B}(2$-year excess BBB return) & 0.42 & 2.61 & 7.93 & -27.52 & 20.27 \\
\hline$r x_{t+2}^{A A A}(2$-year excess AAA return) & -1.05 & 0.59 & 5.65 & -13.59 & 7.91 \\
\hline$r x^{H Y}{ }_{t+3}$ (3-year excess High Yield return) & -0.13 & -0.52 & 15.80 & -42.28 & 36.42 \\
\hline$r x^{B B B}{ }_{t+3}$ (3-year excess BBB return) & 0.79 & 2.22 & 8.98 & -26.35 & 25.56 \\
\hline$r x_{t+3}^{A A A}$ (3-year excess AAA return) & -1.46 & 0.16 & 7.33 & -20.30 & 9.98 \\
\hline $\operatorname{MKTRF}_{t+1}$ & 3.46 & 8.93 & 17.65 & -51.59 & 27.41 \\
\hline$H M L_{t+1}$ & 4.65 & 6.73 & 12.23 & -30.58 & 32.95 \\
\hline$S M B_{t+1}$ & 2.40 & 3.69 & 12.37 & -29.02 & 34.88 \\
\hline$r x_{t+1}^{E D F}$ & -1.89 & 8.93 & 13.14 & -32.93 & 30.12 \\
\hline \multicolumn{6}{|l|}{ Default Rates and Changes in Spreads: } \\
\hline$D E F^{H Y}{ }_{t+1}$ & 3.36 & 2.09 & 3.10 & 0.00 & 12.97 \\
\hline$\Delta_{1}\left(y_{L t+k}^{B B B}-y_{L t+k}^{G}\right)$ & 0.02 & -0.05 & 0.88 & -3.41 & 3.07 \\
\hline$\Delta_{2}\left(y_{L t+k}^{B B B}-y_{L t+k}^{G}\right)$ & 0.11 & 0.06 & 0.95 & -1.41 & 3.87 \\
\hline$\Delta_{3}\left(y_{t+k}^{B B B}-y^{G}\right)$ & 0.15 & 0.19 & 1.01 & -1.89 & 3.49 \\
\hline \multicolumn{6}{|c|}{ Panel E: Intermediary Balance Sheets \% (1962-2008, annual time series) } \\
\hline$E / A_{\text {Bank }}$ & 5.83 & 5.21 & 2.88 & 1.70 & 12.10 \\
\hline$d A / A_{\text {Bank }}$ & 8.21 & 8.57 & 3.68 & -1.39 & 15.26 \\
\hline$E / A_{\text {Insurer }}$ & 12.20 & 12.30 & 1.35 & 8.58 & 14.27 \\
\hline$d A / A_{\text {Insurer }}$ & 8.11 & 8.29 & 4.09 & -8.00 & 15.46 \\
\hline$E / A_{B D}$ & 6.98 & 4.93 & 4.77 & 0.47 & 18.14 \\
\hline$d A / A_{B D}$ & 14.02 & 13.58 & 19.40 & -28.29 & 74.11 \\
\hline$R_{\text {Bank }, t-3, t}$ & 30.79 & 36.29 & 40.36 & -99.42 & 124.55 \\
\hline LoanLosses $_{\text {Bank }}$ & 0.75 & 0.58 & 0.64 & 0.12 & 3.53 \\
\hline
\end{tabular}


Table 2

Issuer Quality and the Returns to Corporate Credit

Univariate time-series forecasting regressions of log excess returns on issuance quality ISS ${ }^{E D F}$ and $\log (H Y S)$ :

$$
r x_{t+k}=a+b \cdot X_{t}+u_{t+k}
$$

$I S S^{E D F}$ is the difference between the expected default frequency deciles of high and low net debt issuers in each year. The high yield (HYS) is the fraction of non-financial corporate bond issuance with a high yield rating from Moody's. In Panel A, the dependent variable is the cumulative 1-, 2-, or 3-year excess return on high yield bonds. In Panel B, the dependent variable is the cumulative 1-, 2-, or 3-year excess return on BBB-rated corporate bonds. In Panel C, the dependent variable is the cumulative 1-, 2-, or 3-year excess return on AAA-rated corporate bonds. $t$-statistics for $k$-period forecasting regressions are based on Newey-West (1987) standard errors allowing for serial correlation up to $k$-lags.

\begin{tabular}{|c|c|c|c|c|c|c|c|c|c|c|c|c|}
\hline & \multicolumn{6}{|c|}{$X_{t}=I S S^{E D F}$} & \multicolumn{6}{|c|}{$X_{t}=\log (H Y S)$} \\
\hline & \multicolumn{3}{|c|}{ Full sample (1962-2008) } & \multicolumn{3}{|c|}{$1983+$} & \multicolumn{3}{|c|}{ Full sample (1926-2008) } & \multicolumn{3}{|c|}{$1983+$} \\
\hline & 1-yr: & 2-yr: & 3-yr: & 1-yr: & 2-yr: & 3-yr: & 1-yr: & 2-yr: & 3-yr: & 1-yr: & 2-yr: & 3-yr: \\
\hline \multicolumn{13}{|c|}{ Panel A: High Yield Excess Returns $\left(r x^{H Y}\right)$} \\
\hline $\begin{array}{l}b \\
{[t]}\end{array}$ & $\begin{array}{r}-9.534 \\
{[3.97]}\end{array}$ & $\begin{array}{r}-15.254 \\
{[5.29]}\end{array}$ & $\begin{array}{r}-17.301 \\
{[3.68]}\end{array}$ & $\begin{array}{r}-11.132 \\
{[2.64]}\end{array}$ & $\begin{array}{r}-21.021 \\
{[5.20]}\end{array}$ & $\begin{array}{r}-27.966 \\
{[6.19]}\end{array}$ & $\begin{array}{c}-1.517 \\
{[1.77]}\end{array}$ & $\begin{array}{c}-2.917 \\
{[1.98]}\end{array}$ & $\begin{array}{l}-3.884 \\
{[1.93]}\end{array}$ & $\begin{array}{r}-11.483 \\
{[2.77]}\end{array}$ & $\begin{array}{r}-14.264 \\
{[4.23]}\end{array}$ & $\begin{array}{r}-17.798 \\
{[5.76}\end{array}$ \\
\hline$R^{2}$ & 0.12 & 0.26 & 0.29 & 0.10 & 0.32 & 0.48 & 0.02 & 0.04 & 0.05 & 0.15 & 0.21 & 0.28 \\
\hline \multicolumn{13}{|c|}{ Panel B: BBB Excess Returns $\left(r x^{B B B}\right)$} \\
\hline $\begin{array}{l}b \\
{[t]}\end{array}$ & $\begin{array}{c}-5.311 \\
{[3.96]}\end{array}$ & $\begin{array}{r}-6.945 \\
{[4.87]}\end{array}$ & $\begin{array}{l}-6.645 \\
{[3.00]}\end{array}$ & $\begin{array}{c}-3.576 \\
{[1.87]}\end{array}$ & $\begin{array}{c}-6.092 \\
{[3.01]}\end{array}$ & $\begin{array}{r}-8.022 \\
{[3.26]}\end{array}$ & $\begin{array}{c}-0.874 \\
{[1.71]}\end{array}$ & $\begin{array}{r}-1.656 \\
{[1.86]}\end{array}$ & $\begin{array}{r}-2.100 \\
{[1.85]}\end{array}$ & $\begin{array}{c}-3.139 \\
{[1.32]}\end{array}$ & $\begin{array}{r}-3.344 \\
{[2.46]}\end{array}$ & $\begin{array}{c}-5.118 \\
{[2.09}\end{array}$ \\
\hline$R^{2}$ & 0.13 & 0.18 & 0.13 & 0.04 & 0.15 & 0.23 & 0.02 & 0.04 & 0.05 & 0.05 & 0.06 & 0.13 \\
\hline \multicolumn{13}{|c|}{ Panel C: AAA Excess Returns $\left(r x^{A A A}\right)$} \\
\hline $\begin{array}{l}b \\
{[t]}\end{array}$ & $\begin{array}{c}-2.278 \\
{[2.43]}\end{array}$ & $\begin{array}{r}-3.321 \\
{[2.55]}\end{array}$ & $\begin{array}{c}-3.372 \\
{[1.50]}\end{array}$ & $\begin{array}{l}-0.799 \\
{[0.95]}\end{array}$ & $\begin{array}{c}-2.184 \\
{[1.38]}\end{array}$ & $\begin{array}{r}-3.578 \\
{[2.03]}\end{array}$ & $\begin{array}{r}-0.310 \\
{[1.17]}\end{array}$ & $\begin{array}{r}-0.473 \\
{[1.03]}\end{array}$ & $\begin{array}{c}-0.108 \\
{[0.19]}\end{array}$ & $\begin{array}{r}-0.030 \\
{[0.07]}\end{array}$ & $\begin{array}{r}-1.015 \\
{[1.07]}\end{array}$ & $\begin{array}{r}-1.920 \\
{[1.14}\end{array}$ \\
\hline$R^{2}$ & 0.10 & 0.08 & 0.05 & 0.02 & 0.07 & 0.13 & 0.02 & 0.01 & 0.00 & 0.00 & 0.02 & 0.05 \\
\hline
\end{tabular}


Table 3

\section{Multivariate Forecasting Regressions}

Time-series forecasting regressions of log excess returns on speculative-grade bonds on measures of debt issuance quality, controlling for the term spread, short-rate, credit spread, and lagged excess returns:

$$
r x_{t+k}^{H Y}=a+b \cdot X_{t}+c \cdot\left(y_{L, t}^{G}-y_{S, t}^{G}\right)+d \cdot y_{S, t}^{G}+e \cdot\left(y_{L, t}^{B B B}-y_{L, t}^{G}\right)+f \cdot r x_{t}^{H Y}+u_{t+k}
$$

In Panel A, $X_{t}$ is $I S S^{E D F}$ from 1962-2008; in Panel B, $X_{t}$ is $I S S^{E D F}$ from 1983-2008; in Panel C, $X_{t}$ is $\log (H Y S)$ from 1926-2008; in Panel D, $X_{t}$ is $\log (H Y S)$ from 1983-2008. $t$-statistics for $k$-period forecasting regressions are based on Newey-West (1987) standard errors allowing for serial correlation up to $k$-lags.

\begin{tabular}{|c|c|c|c|c|c|c|c|c|c|}
\hline & \multicolumn{3}{|c|}{ 1-yr returns } & \multicolumn{3}{|c|}{ 2-yr returns } & \multicolumn{3}{|c|}{ 3-yr returns } \\
\hline \multicolumn{10}{|c|}{ Panel A: $X_{t}=I S S^{E D F}(1962-2008)$} \\
\hline$I S S^{E D F}$ & $\begin{array}{l}-7.636 \\
{[-3.45]}\end{array}$ & $\begin{array}{r}-8.617 \\
{[-2.97]}\end{array}$ & $\begin{array}{c}-6.282 \\
{[-2.40]}\end{array}$ & $\begin{array}{r}-11.022 \\
{[-3.45]}\end{array}$ & $\begin{array}{r}-18.052 \\
{[-4.60]}\end{array}$ & $\begin{array}{r}-13.890 \\
{[-4.54]}\end{array}$ & $\begin{array}{r}-14.214 \\
{[-2.57]}\end{array}$ & $\begin{array}{r}-21.697 \\
{[-3.83]}\end{array}$ & $\begin{array}{r}-19.343 \\
{[-3.77]}\end{array}$ \\
\hline$y_{L, t}^{G}-y_{S, t}^{G}$ & $\begin{array}{r}1.495 \\
{[0.62]}\end{array}$ & & $\begin{array}{c}2.031 \\
{[0.67]}\end{array}$ & $\begin{array}{r}5.025 \\
{[2.25]}\end{array}$ & & $\begin{array}{r}8.055 \\
{[3.36]}\end{array}$ & $\begin{array}{r}4.61 \\
{[2.49]}\end{array}$ & & $\begin{array}{r}9.477 \\
{[5.68]}\end{array}$ \\
\hline$y_{S, t}^{G}$ & $\begin{array}{l}-0.442 \\
{[-0.62]}\end{array}$ & & $\begin{array}{r}-0.49 \\
{[-0.68]}\end{array}$ & $\begin{array}{l}0.487 \\
{[1.02]}\end{array}$ & & $\begin{array}{l}0.845 \\
{[1.40]}\end{array}$ & $\begin{array}{l}1.152 \\
{[1.86]}\end{array}$ & & $\begin{array}{r}2.102 \\
{[3.06]}\end{array}$ \\
\hline$y_{L, t}^{B B B}-y_{L, t}^{G}$ & & $\begin{array}{r}3.836 \\
{[1.29]}\end{array}$ & $\begin{array}{c}3.773 \\
{[1.21]}\end{array}$ & & $\begin{array}{c}-1.498 \\
{[-0.52]}\end{array}$ & $\begin{array}{r}-5.05 \\
{[-1.59]}\end{array}$ & & $\begin{array}{l}-3.595 \\
{[0.86]}\end{array}$ & $\begin{array}{r}-10.624 \\
{[-2.44]}\end{array}$ \\
\hline$r x_{t}^{H Y}$ & & $\begin{array}{l}-0.264 \\
{[-1.77]}\end{array}$ & $\begin{array}{r}-0.29 \\
{[-1.62]}\end{array}$ & & $\begin{array}{l}-0.498 \\
{[-2.35]}\end{array}$ & $\begin{array}{l}-0.729 \\
{[-3.46]}\end{array}$ & & $\begin{array}{l}-0.667 \\
{[3.45]}\end{array}$ & $\begin{array}{l}-0.936 \\
{[-5.20]}\end{array}$ \\
\hline$R^{2}$ & 0.15 & 0.28 & 0.32 & 0.31 & 0.34 & 0.45 & 0.33 & 0.39 & 0.51 \\
\hline \multicolumn{10}{|c|}{ Panel B: $X_{t}=I S S^{E D F}(1983-2008)$} \\
\hline$I S S^{E D F}$ & $\begin{array}{l}-6.120 \\
{[-1.07]}\end{array}$ & $\begin{array}{l}-7.609 \\
{[-1.50]}\end{array}$ & $\begin{array}{c}-4.492 \\
{[-0.85]}\end{array}$ & $\begin{array}{r}-15.578 \\
{[-2.67]}\end{array}$ & $\begin{array}{r}-24.240 \\
{[-5.33]}\end{array}$ & $\begin{array}{r}-15.865 \\
{[-2.49]}\end{array}$ & $\begin{array}{r}-31.055 \\
{[-4.60]}\end{array}$ & $\begin{array}{r}-35.796 \\
{[-5.78]}\end{array}$ & $\begin{array}{r}-35.669 \\
{[-7.09]}\end{array}$ \\
\hline$y_{L, t}^{G}-y_{S, t}^{G}$ & $\begin{array}{c}2.537 \\
{[0.52]}\end{array}$ & & $\begin{array}{l}4.478 \\
{[0.89]}\end{array}$ & $\begin{array}{r}6.687 \\
{[1.57]}\end{array}$ & & $\begin{array}{r}10.175 \\
{[2.16]}\end{array}$ & $\begin{array}{r}3.773 \\
{[1.41]}\end{array}$ & & $\begin{array}{r}7.136 \\
{[3.08]}\end{array}$ \\
\hline$y_{S, t}^{G}$ & $\begin{array}{r}-1.036 \\
{[-0.60]}\end{array}$ & & $\begin{array}{l}0.392 \\
{[0.27]}\end{array}$ & $\begin{array}{l}0.608 \\
{[0.67]}\end{array}$ & & $\begin{array}{c}0.262 \\
{[0.26]}\end{array}$ & $\begin{array}{l}2.874 \\
{[3.02]}\end{array}$ & & $\begin{array}{r}2.566 \\
{[2.90]}\end{array}$ \\
\hline$y_{L, t}^{B B B}-y_{L, t}^{G}$ & & $\begin{array}{c}9.948 \\
{[2.00]}\end{array}$ & $\begin{array}{r}9.214 \\
{[1.88]}\end{array}$ & & $\begin{array}{c}-4.242 \\
{[-0.48]}\end{array}$ & $\begin{array}{l}-6.044 \\
{[-0.70]}\end{array}$ & & $\begin{array}{r}-15.979 \\
{[-1.83]}\end{array}$ & $\begin{array}{r}-17.903 \\
{[-2.11]}\end{array}$ \\
\hline$r x_{t}^{H Y}$ & & $\begin{array}{l}-0.020 \\
{[-0.08]}\end{array}$ & $\begin{array}{c}-0.114 \\
{[-0.45]}\end{array}$ & & $\begin{array}{l}-0.536 \\
{[-2.29]}\end{array}$ & $\begin{array}{l}-0.773 \\
{[-3.07]}\end{array}$ & & $\begin{array}{l}-0.823 \\
{[-4.80]}\end{array}$ & $\begin{array}{r}-0.899 \\
{[-7.66]}\end{array}$ \\
\hline$R^{2}$ & 0.13 & 0.33 & 0.35 & 0.37 & 0.39 & 0.51 & 0.56 & 0.60 & 0.70 \\
\hline \multicolumn{10}{|c|}{ Panel C: $X_{t}=\log (H Y S)(1926-2008)$} \\
\hline $\log (H Y S)$ & $\begin{array}{l}-1.495 \\
{[-1.88]}\end{array}$ & $\begin{array}{r}-1.925 \\
{[-2.32]}\end{array}$ & $\begin{array}{c}-1.717 \\
{[-2.14]}\end{array}$ & $\begin{array}{r}-3.154 \\
{[-2.51]}\end{array}$ & $\begin{array}{r}-3.438 \\
{[-2.57]}\end{array}$ & $\begin{array}{r}-3.250 \\
{[-2.63]}\end{array}$ & $\begin{array}{c}-4.067 \\
{[-2.21]}\end{array}$ & $\begin{array}{l}-4.543 \\
{[-2.23]}\end{array}$ & $\begin{array}{r}-4.254 \\
{[-2.20]}\end{array}$ \\
\hline$y_{L, t}^{G}-y_{S, t}^{G}$ & $\begin{array}{c}2.201 \\
{[1.20]}\end{array}$ & & $\begin{array}{c}0.275 \\
{[0.12]}\end{array}$ & $\begin{array}{r}6.269 \\
{[2.47]}\end{array}$ & & $\begin{array}{c}5.577 \\
{[1.46]}\end{array}$ & $\begin{array}{l}5.555 \\
{[1.31]}\end{array}$ & & $\begin{array}{c}3.076 \\
{[0.51]}\end{array}$ \\
\hline$y_{S, t}^{G}$ & $\begin{array}{r}-0.375 \\
{[-0.78]}\end{array}$ & & $\begin{array}{c}-0.514 \\
{[-0.94]}\end{array}$ & $\begin{array}{c}-0.054 \\
{[-0.07]}\end{array}$ & & $\begin{array}{c}-0.057 \\
{[-0.06]}\end{array}$ & $\begin{array}{r}-0.240 \\
{[-0.20]}\end{array}$ & & $\begin{array}{r}-0.515 \\
{[-0.38]}\end{array}$ \\
\hline$y_{L, t}^{B B B}-y_{L, t}^{G}$ & & $\begin{array}{r}3.492 \\
{[1.53]}\end{array}$ & $\begin{array}{r}2.936 \\
{[1.13]}\end{array}$ & & $\begin{array}{c}4.552 \\
{[1.60]}\end{array}$ & $\begin{array}{l}1.024 \\
{[0.28]}\end{array}$ & & $\begin{array}{r}5.904 \\
{[1.78]}\end{array}$ & $\begin{array}{r}3.658 \\
{[0.76]}\end{array}$ \\
\hline$r x_{t}^{\mathrm{HY}}$ & & $\begin{array}{l}0.172 \\
{[1.06]}\end{array}$ & $\begin{array}{r}0.131 \\
{[0.80]}\end{array}$ & & $\begin{array}{l}0.307 \\
{[1.27]}\end{array}$ & $\begin{array}{r}0.130 \\
{[0.49]}\end{array}$ & & $\begin{array}{l}0.201 \\
{[0.73]}\end{array}$ & $\begin{array}{c}0.067 \\
{[0.21]}\end{array}$ \\
\hline$R^{2}$ & 0.07 & 0.07 & 0.09 & 0.14 & 0.09 & 0.14 & 0.11 & 0.10 & 0.12 \\
\hline \multicolumn{10}{|c|}{ Panel D: $X_{t}=\log (H Y S)(1983-2008)$} \\
\hline $\log (H Y S)$ & $\begin{array}{r}-11.180 \\
{[-2.89]}\end{array}$ & $\begin{array}{c}-6.632 \\
{[-1.58]}\end{array}$ & $\begin{array}{c}-5.326 \\
{[-1.20]}\end{array}$ & $\begin{array}{r}-11.889 \\
{[-3.21]}\end{array}$ & $\begin{array}{r}-12.432 \\
{[-3.12]}\end{array}$ & $\begin{array}{r}-9.525 \\
{[-2.32]}\end{array}$ & $\begin{array}{r}-15.000 \\
{[-5.05]}\end{array}$ & $\begin{array}{r}-17.516 \\
{[-4.02]}\end{array}$ & $\begin{array}{r}-14.451 \\
{[-5.19]}\end{array}$ \\
\hline$y_{L, t}^{G}-y_{S, t}^{G}$ & $\begin{array}{c}1.803 \\
{[0.39]}\end{array}$ & & $\begin{array}{l}4.203 \\
{[0.81]}\end{array}$ & $\begin{array}{r}8.188 \\
{[2.10]}\end{array}$ & & $\begin{array}{c}11.651 \\
{[2.55]}\end{array}$ & $\begin{array}{r}8.269 \\
{[2.34]}\end{array}$ & & $\begin{array}{r}11.254 \\
{[3.52]}\end{array}$ \\
\hline$y_{s, t}^{G}$ & $\begin{array}{l}-1.751 \\
{[-1.19]}\end{array}$ & & $\begin{array}{l}-0.225 \\
{[-0.15]}\end{array}$ & $\begin{array}{l}-1.052 \\
{[-1.14]}\end{array}$ & & $\begin{array}{l}-1.173 \\
{[-1.11]}\end{array}$ & $\begin{array}{l}-0.105 \\
{[-0.08]}\end{array}$ & & $\begin{array}{l}-0.430 \\
{[-0.34]}\end{array}$ \\
\hline$y_{L, t}^{B B B}-y_{L, t}^{G}$ & & $\begin{array}{c}11.227 \\
{[2.42]}\end{array}$ & $\begin{array}{c}8.335 \\
{[1.56]}\end{array}$ & & $\begin{array}{l}5.693 \\
{[0.53]}\end{array}$ & $\begin{array}{l}-4.489 \\
{[-0.57]}\end{array}$ & & $\begin{array}{c}-0.161 \\
{[-0.01]}\end{array}$ & $\begin{array}{l}-9.068 \\
{[-0.85]}\end{array}$ \\
\hline$r x_{t}^{\text {Ну }}$ & & $\begin{array}{c}0.138 \\
{[0.56]}\end{array}$ & $\begin{array}{c}-0.059 \\
{[-0.27]}\end{array}$ & & $\begin{array}{l}-0.025 \\
{[-0.08]}\end{array}$ & $\begin{array}{l}-0.620 \\
{[-2.20]}\end{array}$ & & $\begin{array}{l}-0.077 \\
{[-0.22]}\end{array}$ & $\begin{array}{l}-0.585 \\
{[-2.79]}\end{array}$ \\
\hline$R^{2}$ & 0.24 & 0.33 & 0.36 & 0.40 & 0.22 & 0.48 & 0.39 & 0.28 & 0.45 \\
\hline
\end{tabular}


Table 4

\section{Quantity and Quality and Future Returns to Credit}

Annual time-series regressions of the form $r x_{t+2}^{H Y}=a+b \cdot X_{t}+c \cdot\left(y_{L, t}^{G}-y_{S, t}^{G}\right)+d \cdot y_{S, t}^{G}+e \cdot\left(y_{L, t}^{B B}-y_{L, t}^{G}\right)+f \cdot r x_{t}^{H Y}+u_{t+2}$, where $r x^{H Y}$ is the cumulative 2-year excess return on high yield bonds, $\Delta D_{A g g} / D_{\text {Agg }}$ is the annual percentage change in total debt for nonfinancial Compustat firms, $\Delta D_{k} / D_{\mathrm{k}}$ denotes aggregate debt growth in NYSE EDF deciles $k$. Panel A shows regressions without controls. Panel B shows regressions with controls: the term spread, short-rate, credit spread, lagged excess high yield returns. $t$-statistics are based on Newey-West (1987) standard errors allowing for serial correlation up to 2-lags.

\begin{tabular}{|c|c|c|c|c|c|c|c|c|c|c|c|c|}
\hline & \multicolumn{12}{|c|}{ Panel A: Univariate } \\
\hline & & $(1)$ & $(2)$ & (3) & (4) & (5) & (6) & (7) & (8) & (9) & (10) & (11) \\
\hline Issuer Quality & $I S S^{E D F}$ & $\begin{array}{r}-15.254 \\
{[-5.29]}\end{array}$ & & $\begin{array}{r}-12.978 \\
{[-3.78]}\end{array}$ & & & & & & & & \\
\hline Agg. debt growth & $\Delta D_{\text {Agg }} / D_{\text {Agg }}$ & & $\begin{array}{r}-5.212 \\
{[-3.97]}\end{array}$ & $\begin{array}{l}-2.433 \\
{[-1.49]}\end{array}$ & & & & & & & & \\
\hline Low EDF & $\Delta D_{1} / D_{1}$ & & & & $\begin{array}{r}-3.474 \\
{[-2.04]}\end{array}$ & & & & & $\begin{array}{l}-1.565 \\
{[-0.86]}\end{array}$ & & $\begin{array}{l}-4.917 \\
{[-3.16]}\end{array}$ \\
\hline 2 & $\Delta D_{2} / D_{2}$ & & & & & $\begin{array}{l}-3.806 \\
{[-2.97]}\end{array}$ & & & & & & \\
\hline 3 & $\Delta D_{3} / D_{3}$ & & & & & & $\begin{array}{l}-2.842 \\
{[-2.31]}\end{array}$ & & & & & \\
\hline 4 & $\Delta D_{4} / D_{4}$ & & & & & & & $\begin{array}{l}-4.025 \\
{[-1.92]}\end{array}$ & & & & \\
\hline High EDF & $\Delta D_{5} / D_{5}$ & & & & & & & & $\begin{array}{l}-7.091 \\
{[-3.76]}\end{array}$ & $\begin{array}{l}-6.631 \\
{[-3.09]}\end{array}$ & & \\
\hline High-Low & $\Delta D_{5} / D_{5}-\Delta D_{1} / D_{1}$ & & & & & & & & & & $\begin{array}{l}-5.420 \\
{[-2.39]}\end{array}$ & $\begin{array}{l}-6.538 \\
{[-3.09]}\end{array}$ \\
\hline & $R^{2}$ & 0.26 & 0.13 & 0.29 & 0.06 & 0.07 & 0.04 & 0.08 & 0.24 & 0.26 & 0.14 & 0.26 \\
\hline \multicolumn{13}{|c|}{ Panel B: Including additional time-series controls } \\
\hline Issuer Quality & $I S S^{E D F}$ & $\begin{array}{r}-13.890 \\
{[-4.54]}\end{array}$ & & $\begin{array}{r}-11.442 \\
{[-3.73]}\end{array}$ & & & & & & & & \\
\hline Agg. debt growth & $\Delta D_{\text {Agg }} / D_{\text {Agg }}$ & & $\begin{array}{l}-6.497 \\
{[-3.22]}\end{array}$ & $\begin{array}{l}-5.126 \\
{[-2.40]}\end{array}$ & & & & & & & & \\
\hline Low EDF & $\Delta D_{1} / D_{1}$ & & & & $\begin{array}{l}-3.329 \\
{[-1.77]}\end{array}$ & & & & & $\begin{array}{l}-2.357 \\
{[-1.23]}\end{array}$ & & $\begin{array}{l}-5.808 \\
{[-2.49]}\end{array}$ \\
\hline 2 & $\Delta D_{2} / D_{2}$ & & & & & $\begin{array}{l}-2.367 \\
{[-1.17]}\end{array}$ & & & & & & \\
\hline 3 & $\Delta D_{3} / D_{3}$ & & & & & & $\begin{array}{l}-3.104 \\
{[-1.96]}\end{array}$ & & & & & \\
\hline 4 & $\Delta D_{4} / D_{4}$ & & & & & & & $\begin{array}{l}-4.629 \\
{[-2.68]}\end{array}$ & & & & \\
\hline High EDF & $\Delta D_{5} / D_{5}$ & & & & & & & & $\begin{array}{l}-7.053 \\
{[-3.21]}\end{array}$ & $\begin{array}{c}-6.827 \\
{[-3.04]}\end{array}$ & & \\
\hline \multirow[t]{2}{*}{ High-Low } & $\Delta D_{5} / D_{5}-\Delta D_{1} / D_{1}$ & & & & & & & & & & $\begin{array}{l}-5.429 \\
{[2.60]}\end{array}$ & $\begin{array}{l}-6.731 \\
{[-3.04]}\end{array}$ \\
\hline & $R^{2}$ & 0.45 & 0.43 & 0.51 & 0.34 & 0.33 & 0.34 & 0.39 & 0.51 & 0.52 & 0.44 & 0.52 \\
\hline
\end{tabular}




\section{Table 5 \\ Robustness}

Robustness checks on the time-series forecasting regression from Tables 2 and 3

$$
r x_{t+2}^{H Y}=a+b \cdot I S S_{t}^{E D F}+c \cdot\left(y_{L, t}^{G}-y_{S, t}^{G}\right)+d \cdot y_{S, t}^{G}+e \cdot\left(y_{L, t}^{B B B}-y_{L, t}^{G}\right)+f \cdot r x_{t}^{H Y}+u_{t+2}
$$

The dependent variable is the 2-year cumulative excess log return on high yield bonds. The table reports the coefficient and $t$-statistic on the main variable of interest, $I S S^{E D F}$, as well as the regression $R^{2}$. The multivariate specifications include controls for the term spread, short-rate, credit spread, and lagged excess high yield returns. We adjustment the baseline regression in row (1) in a number of ways. Rows (2)-(5) present subsample results. In rows (6)-(11) we consider additional controls, including the output gap (Hodrick-Prescott filtered real GDP) in (6); other macroeconomic controls (industrial production, consumption growth, and a recession dummy) in (7); leads and lags of those macro controls in (8); the 8 macro factors from Ludvigson and $\mathrm{Ng}$ (2010) in (9); cay from Lettau and Ludvigson (2001) in (10); and the CochranePiazzesi (2005) tent factor in (11). Rows (12)-(17) consider alternate constructions of ISS ${ }^{E D F}$. Rows (18)-(24) consider alternate qualityrelated firm characteristics, including the Shumway (2001) bankruptcy hazard, interest coverage, leverage, idiosyncratic volatility, market capitalization, age, and payout policy. Finally, rows (25) and (26) control for ontemporaneous equity market returns in (25); and for contemporaneous realizations of the Fama and French (1993) factors in (26). $t$-statistics are based on Newey-West (1987) standard errors allowing for serial correlation up to 2 lags.

\begin{tabular}{|c|c|c|c|c|c|c|c|}
\hline \multirow[b]{3}{*}{ (1) } & \multirow[b]{3}{*}{$\underline{\text { Baseline Result }}$} & \multicolumn{3}{|c|}{ Univariate } & \multicolumn{3}{|c|}{ With time-series controls } \\
\hline & & $b$ & {$[\mathrm{t}]$} & $R^{2}$ & $b$ & {$[\mathrm{t}]$} & $\overline{R^{2}}$ \\
\hline & & -15.254 & {$[-5.29]$} & 0.26 & -13.890 & {$[-4.54]$} & 0.45 \\
\hline & $\underline{\text { Subsamples: }}$ & & & & & & \\
\hline (2) & Longer 1952-2008 sample & -9.403 & {$[-3.03]$} & 0.16 & -8.367 & {$[-3.00]$} & 0.38 \\
\hline (3) & Pre-1983 & -8.994 & {$[-3.90]$} & 0.23 & -9.383 & {$[-2.48]$} & 0.40 \\
\hline (4) & 1983-Present & -21.021 & {$[-5.20]$} & 0.32 & -15.865 & {$[-2.49]$} & 0.51 \\
\hline \multirow[t]{2}{*}{ (5) } & Dropping 2008-2009 & -14.556 & {$[-5.32]$} & 0.33 & -13.997 & {$[-4.33]$} & 0.47 \\
\hline & Additional Controls: & & & & & & \\
\hline (6) & Output Gapl & -13.592 & {$[-4.05]$} & 0.27 & -13.548 & {$[-4.32]$} & 0.46 \\
\hline (7) & Other Macro Variables & -12.975 & {$[-2.97]$} & 0.30 & -10.045 & {$[-3.08]$} & 0.50 \\
\hline (8) & Leads/Lags of Macro Variables & -11.834 & {$[-2.67]$} & 0.46 & -11.639 & {$[-2.36]$} & 0.59 \\
\hline (9) & Eight macro factors & -12.303 & {$[-4.29]$} & 0.48 & -13.659 & {$[-4.13]$} & 0.56 \\
\hline (10) & Cay & -12.910 & {$[-3.99]$} & 0.41 & -11.550 & {$[-3.11]$} & 0.49 \\
\hline \multirow[t]{2}{*}{ (11) } & Cochrane-Piazzessi Tent Factor & -14.499 & {$[-4.87]$} & 0.30 & -13.818 & {$[-3.66]$} & 0.45 \\
\hline & Alternate Constructions of ISS ${ }^{E D F}$ : & & & & & & \\
\hline$(12)$ & Debt Iss, EDF Level & -372.414 & {$[-5.37]$} & 0.26 & -274.561 & {$[-6.72]$} & 0.44 \\
\hline (13) & Long-term Debt Iss, EDF Decile & -18.663 & {$[-4.28]$} & 0.24 & -15.087 & {$[-4.21]$} & 0.44 \\
\hline (14) & Short-term Debt Iss, EDF Decile & -3.531 & {$[-0.86]$} & 0.02 & -3.668 & {$[-0.98]$} & 0.33 \\
\hline (15) & Asset Weighted & -5.890 & {$[-3.83]$} & 0.21 & -3.700 & {$[-2.70]$} & 0.38 \\
\hline (16) & Debt Iss Weighted & -4.970 & {$[-3.44]$} & 0.16 & -3.597 & {$[-3.20]$} & 0.39 \\
\hline \multirow[t]{2}{*}{ (17) } & Nonfinancials Only & -15.178 & {$[-4.02]$} & 0.21 & -13.234 & {$[-3.64]$} & 0.42 \\
\hline & Alternate Measures of Credit Quality: & & & & & & \\
\hline (18) & Shumway Distress & -18.751 & {$[-3.60]$} & 0.18 & -15.560 & {$[-3.31]$} & 0.40 \\
\hline (19) & Interest coverage (Low - High) & -15.318 & {$[-3.41]$} & 0.16 & -12.077 & {$[-2.51]$} & 0.39 \\
\hline (20) & Leverage (Debt/Assets) & -7.804 & {$[-2.42]$} & 0.10 & -4.711 & {$[-1.30]$} & 0.34 \\
\hline$(21)$ & $\mathrm{CAPM} \sigma$ & -8.696 & {$[-3.25]$} & 0.11 & -4.310 & {$[-0.91]$} & 0.33 \\
\hline$(22)$ & Size (Small - Big) & -10.967 & {$[-1.71]$} & 0.05 & -3.222 & {$[-0.50]$} & 0.32 \\
\hline (23) & Age (Young - Old) & -15.141 & {$[-2.38]$} & 0.07 & -16.263 & {$[-2.18]$} & 0.37 \\
\hline \multirow[t]{2}{*}{ (24) } & Dividends (Non-payer - Payer) & -83.443 & {$[-2.84]$} & 0.12 & -69.163 & {$[-2.15]$} & 0.37 \\
\hline & Link to Equity Market: & & & & & & \\
\hline$(25)$ & Contemporaneous Equity Returns (MKTRF) & -13.409 & {$[-5.32]$} & 0.64 & -12.232 & {$[-3.80]$} & 0.72 \\
\hline (26) & Contemporaneous Fama-French Factors & -11.011 & {$[-4.88]$} & 0.69 & -12.603 & {$[-4.79]$} & 0.76 \\
\hline
\end{tabular}


Table 6

\section{Forecasting Changes in Credit Spreads and Defaults}

Annual time-series forecasting regressions of changes in BBB-rated credit spreads:

$$
\begin{gathered}
\Delta_{k}\left(y_{L, t+k}^{B B B}-y_{L, t+k}^{G}\right)=a+b \cdot I S S_{t}^{E D F}+c \cdot\left(y_{L, t}^{G}-y_{S, t}^{G}\right)+d \cdot y_{S, t}^{G}+e \cdot\left(y_{L, t}^{B B B}-y_{L, t}^{G}\right)+f \cdot r x_{t}^{H Y}+g \cdot D E F_{t}^{H Y}+u_{t+k} \cdot \\
D E F_{t+k}^{H Y}=a+b_{1} \cdot I S S_{t}^{E D F}+b_{2} \cdot D E F_{t}^{H Y}+c \cdot\left(y_{L, t}^{G}-y_{S, t}^{G}\right)+d \cdot y_{S, t}^{G}+e \cdot\left(y_{L, t}^{B B B}-y_{L, t}^{G}\right)+f \cdot r x_{t}^{H Y}+u_{t+k},
\end{gathered}
$$

where $\Delta_{k}$ denotes the $k$-year difference, $D E F_{t+k}^{H Y}$ denotes the issuer-weighted default rate for high yield bonds in year $t+k$ from the annual Moody's default survey, $y^{B B B}-y^{G}$ is the credit spread, and $I S S^{E D F}$ is the difference between the expected default frequency decile of high and low net debt issuers in each year. Control variables include the term spread, short-rate, credit spread, lagged excess high yield returns, and the time- $t$ default rate. $t$-statistics for $k$-period forecasting regressions are based on Newey-West (1987) standard errors allowing for

\begin{tabular}{|c|c|c|c|c|c|c|c|c|c|c|c|c|c|c|c|}
\hline & \multicolumn{9}{|c|}{ Change in Credit Spreads } & \multicolumn{6}{|c|}{ Defaults in Year: } \\
\hline & \multicolumn{3}{|c|}{$\begin{array}{c}\text { 1-year change } \\
\Delta_{1}\left(y_{L, t+1}^{B B B}-y_{L, t+1}^{G}\right)\end{array}$} & \multicolumn{3}{|c|}{$\begin{array}{c}\text { 2-year change } \\
\Delta_{2}\left(y_{L, t+2}^{B B B}-y_{L, t+2}^{G}\right)\end{array}$} & \multicolumn{3}{|c|}{$\begin{array}{c}\text { 3-year change } \\
\Delta_{3}\left(y_{L, t+3}^{B B B}-y_{L, t+3}^{G}\right)\end{array}$} & \multicolumn{2}{|c|}{$t+1$} & \multicolumn{2}{|c|}{$t+2$} & \multicolumn{2}{|c|}{$t+3$} \\
\hline$I S S^{E D F}$ & $\begin{array}{r}0.609 \\
{[4.07]}\end{array}$ & $\begin{array}{c}0.352 \\
{[2.26]}\end{array}$ & $\begin{array}{c}0.237 \\
{[1.45]}\end{array}$ & $\begin{array}{r}0.925 \\
{[5.33]}\end{array}$ & $\begin{array}{r}0.449 \\
{[1.85]}\end{array}$ & $\begin{array}{r}0.419 \\
{[2.14]}\end{array}$ & $\begin{array}{r}0.879 \\
{[6.25]}\end{array}$ & $\begin{array}{r}0.519 \\
{[1.81]}\end{array}$ & $\begin{array}{r}0.296 \\
{[1.05]}\end{array}$ & $\begin{array}{c}1.502 \\
{[2.48]}\end{array}$ & $\begin{array}{c}1.352 \\
{[2.39]}\end{array}$ & $\begin{array}{r}2.990 \\
{[3.53]}\end{array}$ & $\begin{array}{c}3.322 \\
{[4.62]}\end{array}$ & $\begin{array}{l}2.488 \\
{[1.78]}\end{array}$ & $\begin{array}{r}3.269 \\
{[1.91]}\end{array}$ \\
\hline$y_{L, t}^{G}-y_{S, t}^{G}$ & & $\begin{array}{c}-0.244 \\
{[-1.39]}\end{array}$ & $\begin{array}{r}-0.280 \\
{[-1.75]}\end{array}$ & & $\begin{array}{c}-0.582 \\
{[-2.59]}\end{array}$ & $\begin{array}{r}-0.631 \\
{[-2.23]}\end{array}$ & & $\begin{array}{c}-0.562 \\
{[-2.36]}\end{array}$ & $\begin{array}{c}-0.427 \\
{[-1.91]}\end{array}$ & & $\begin{array}{c}0.281 \\
{[0.41]}\end{array}$ & & $\begin{array}{c}-0.827 \\
{[-1.20]}\end{array}$ & & $\begin{array}{c}-1.063 \\
{[-1.25]}\end{array}$ \\
\hline$y_{S, t}^{G}$ & & $\begin{array}{c}0.024 \\
{[0.43]}\end{array}$ & $\begin{array}{c}0.042 \\
{[0.86]}\end{array}$ & & $\begin{array}{l}-0.070 \\
{[-1.62]}\end{array}$ & $\begin{array}{c}0.004 \\
{[0.09]}\end{array}$ & & $\begin{array}{c}-0.156 \\
{[-3.46]}\end{array}$ & $\begin{array}{r}-0.066 \\
{[-0.98]}\end{array}$ & & $\begin{array}{c}0.005 \\
{[0.03]}\end{array}$ & & $\begin{array}{c}-0.084 \\
{[-0.34]}\end{array}$ & & $\begin{array}{c}-0.033 \\
{[-0.22]}\end{array}$ \\
\hline$y_{L, t}^{B B B}-y_{L, t}^{G}$ & & & $\begin{array}{l}-0.523 \\
{[-3.32]}\end{array}$ & & & $\begin{array}{l}-0.668 \\
{[-2.78]}\end{array}$ & & & $\begin{array}{l}-0.663 \\
{[-1.76]}\end{array}$ & & $\begin{array}{r}0.824 \\
{[1.39]}\end{array}$ & & $\begin{array}{c}1.401 \\
{[1.23]}\end{array}$ & & $\begin{array}{r}1.501 \\
{[1.53]}\end{array}$ \\
\hline$r x_{t}^{H Y}$ & & & $\begin{array}{r}0.010 \\
{[1.53]}\end{array}$ & & & $\begin{array}{r}0.025 \\
{[1.34]}\end{array}$ & & & $\begin{array}{r}0.020 \\
{[-1.50]}\end{array}$ & & $\begin{array}{c}-0.084 \\
{[-2.05]}\end{array}$ & & $\begin{array}{r}0.048 \\
{[1.12]}\end{array}$ & & $\begin{array}{r}0.128 \\
{[2.01]}\end{array}$ \\
\hline$D E F^{H Y}$ & & & $\begin{array}{c}0.052 \\
{[1.50]}\end{array}$ & & & $\begin{array}{r}0.093 \\
{[2.17]}\end{array}$ & & & $\begin{array}{l}-0.013 \\
{[-0.27]}\end{array}$ & $\begin{array}{r}0.786 \\
{[4.08]}\end{array}$ & $\begin{array}{r}0.618 \\
{[2.31]}\end{array}$ & $\begin{array}{r}0.614 \\
{[3.53]}\end{array}$ & $\begin{array}{r}0.681 \\
{[2.90]}\end{array}$ & $\begin{array}{r}0.359 \\
{[2.04]}\end{array}$ & $\begin{array}{r}0.538 \\
{[2.47]}\end{array}$ \\
\hline$R^{2}$ & 0.11 & 0.17 & 0.45 & 0.22 & 0.36 & 0.60 & 0.18 & 0.36 & 0.55 & 0.37 & 0.56 & 0.25 & 0.30 & 0.13 & 0.22 \\
\hline
\end{tabular}
serial correlation up to $k$-lags. 
Table 7

Intermediary Balance Sheets and Issuer Quality

This table explores the relationship between $I S S^{E D F}$ and measures of intermediary balance sheet strength $Z$. The first two columns in each panel report the coefficient on $Z_{t}$ from regressions of the form

$$
I S S_{t}^{E D F}=a+b \cdot Z_{t}+c \cdot\left(y_{L, t}^{G}-y_{S, t}^{G}\right)+d \cdot y_{S, t}^{G}+e \cdot\left(y_{L, t}^{B B B}-y_{L, t}^{G}\right)+f \cdot r x_{t}^{H Y}+u_{t+k} \cdot
$$

Columns (3) to (6) report the coefficients on $I S S^{E D F}$ and $Z_{t}$ from return forecasting regressions of the form

$$
r x_{t+2}^{H Y}=a+b \cdot I S S_{t}^{E D F}+b \cdot Z_{t}+c \cdot\left(y_{L, t}^{G}-y_{S, t}^{G}\right)+d \cdot y_{S, t}^{G}+e \cdot\left(y_{L, t}^{B B B}-y_{L, t}^{G}\right)+f \cdot r x_{t}^{H Y}+u_{t+2},
$$

where $r x^{H Y}$ denotes the 2-year excess return on high yield bonds. The regressions alternately omit ISS ${ }^{E D F}$, and include the term spread, short-rate, credit spread, and lagged excess high yield returns as controls. Measures of intermediary balance sheet strength, summarized in Table 1, include insurer equity capital $E / A$ (total assets minus liabilities all over assets) and balance sheet growth $d A / A$ (year-over-year percentage change in total assets); broker dealer equity capital $E / A$ and balance sheet growth $d A / A$; bank equity capital $E / A$ and balance sheet growth $d A / A$; lagged equal weighted returns on bank stocks based on Fama and French 48-industry classifications; and bank loan loss provisions scaled by total loans and leases. $t$-statistics for 2-year forecasting regressions are based

\begin{tabular}{|c|c|c|c|c|c|c|c|}
\hline & & \multicolumn{2}{|c|}{ Depvar: $I S S^{E D F}$} & \multicolumn{4}{|c|}{ Depvar: $r x_{t+2}^{H Y}$} \\
\hline & & (1) & $(2)$ & (3) & (4) & (5) & (6) \\
\hline \multirow[t]{5}{*}{ Insurer Balance Sheets } & $I S S^{E D F}$ & & & & $\begin{array}{r}-13.102 \\
{[-3.41]}\end{array}$ & & $\begin{array}{r}-14.251 \\
{[-3.69]}\end{array}$ \\
\hline & $E / A_{\text {Insurer }}$ & $\begin{array}{r}0.156 \\
{[3.58]}\end{array}$ & $\begin{array}{r}0.133 \\
{[2.54]}\end{array}$ & $\begin{array}{l}-4.104 \\
{[-3.78]}\end{array}$ & $\begin{array}{l}-2.058 \\
{[-1.68]}\end{array}$ & $\begin{array}{l}-1.336 \\
{[-0.76]}\end{array}$ & $\begin{array}{r}0.563 \\
{[0.33]}\end{array}$ \\
\hline & $d A / A_{\text {Insurer }}$ & $\begin{array}{r}-0.008 \\
{[-0.35]}\end{array}$ & $\begin{array}{l}-0.005 \\
{[-0.21]}\end{array}$ & $\begin{array}{c}-0.382 \\
{[-0.89]}\end{array}$ & $\begin{array}{l}-0.493 \\
{[-1.06]}\end{array}$ & $\begin{array}{c}0.382 \\
{[0.70]}\end{array}$ & $\begin{array}{r}0.314 \\
{[0.53]}\end{array}$ \\
\hline & Controls & No & Yes & No & No & Yes & Yes \\
\hline & $R^{2}$ & 0.21 & 0.48 & 0.15 & 0.30 & 0.33 & 0.45 \\
\hline \multirow[t]{5}{*}{ Broker-Dealer Balance Sheets } & $I S S^{E D F}$ & & & & $\begin{array}{r}-16.006 \\
{[-5.25]}\end{array}$ & & $\begin{array}{r}-14.579 \\
{[-4.20]}\end{array}$ \\
\hline & $E / A_{B D}$ & $\begin{array}{c}-0.017 \\
{[-0.98]}\end{array}$ & $\begin{array}{l}-0.018 \\
{[0.86]}\end{array}$ & $\begin{array}{r}0.160 \\
{[0.31]}\end{array}$ & $\begin{array}{r}-0.105 \\
{[-0.27]}\end{array}$ & $\begin{array}{r}-0.025 \\
{[-0.04]}\end{array}$ & $\begin{array}{l}-0.289 \\
{[-0.55]}\end{array}$ \\
\hline & $d A / A_{B D}$ & $\begin{array}{l}-0.005 \\
{[-1.60]}\end{array}$ & $\begin{array}{l}-0.003 \\
{[-1.06]}\end{array}$ & $\begin{array}{l}-0.008 \\
{[-0.08]}\end{array}$ & $\begin{array}{l}-0.088 \\
{[-0.96]}\end{array}$ & $\begin{array}{l}-0.035 \\
{[-0.49]}\end{array}$ & $\begin{array}{l}-0.080 \\
{[-1.58]}\end{array}$ \\
\hline & Controls & No & Yes & No & No & Yes & Yes \\
\hline & $R^{2}$ & 0.06 & 0.42 & 0.00 & 0.28 & 0.32 & 0.46 \\
\hline \multirow[t]{5}{*}{ Bank Balance Sheets } & $I S S^{E D F}$ & & & & $\begin{array}{r}-14.032 \\
{[-4.28]}\end{array}$ & & $\begin{array}{r}-13.648 \\
{[-4.81]}\end{array}$ \\
\hline & $E / A_{\text {Bank }}$ & $\begin{array}{c}-0.013 \\
{[-0.40]}\end{array}$ & $\begin{array}{c}-0.032 \\
{[-0.96]}\end{array}$ & $\begin{array}{c}-0.558 \\
{[0.50]}\end{array}$ & $\begin{array}{r}-0.734 \\
{[0.88]}\end{array}$ & $\begin{array}{c}-0.208 \\
{[-0.15]}\end{array}$ & $\begin{array}{l}-0.642 \\
{[-0.51]}\end{array}$ \\
\hline & $d A / A_{\text {Bank }}$ & $\begin{array}{r}0.036 \\
{[1.48]}\end{array}$ & $\begin{array}{r}0.019 \\
{[0.71]}\end{array}$ & $\begin{array}{l}-1.285 \\
{[-2.64]}\end{array}$ & $\begin{array}{r}-0.780 \\
{[-1.60]}\end{array}$ & $\begin{array}{r}-0.768 \\
{[-1.58]}\end{array}$ & $\begin{array}{l}-0.512 \\
{[-1.04]}\end{array}$ \\
\hline & Controls & No & Yes & No & No & Yes & Yes \\
\hline & $R^{2}$ & 0.07 & 0.43 & 0.12 & 0.32 & 0.35 & 0.47 \\
\hline \multirow[t]{4}{*}{ Lagged Bank Stock Returns } & $I S S^{E D F}$ & & & & $\begin{array}{r}-13.927 \\
{[-4.19]}\end{array}$ & & $\begin{array}{r}-13.165 \\
{[-3.73]}\end{array}$ \\
\hline & $R_{\text {Bank }, t-3, t}$ & $\begin{array}{r}0.005 \\
{[2.54]} \\
\end{array}$ & $\begin{array}{r}0.004 \\
{[3.36]} \\
\end{array}$ & $\begin{array}{r}-0.105 \\
{[-3.60]}\end{array}$ & $\begin{array}{r}-0.039 \\
{[-1.18]} \\
\end{array}$ & $\begin{array}{r}-0.068 \\
{[-2.40]}\end{array}$ & $\begin{array}{r}-0.018 \\
{[-0.50]} \\
\end{array}$ \\
\hline & Controls & No & Yes & No & No & Yes & Yes \\
\hline & $R^{2}$ & 0.16 & 0.50 & 0.09 & 0.27 & 0.35 & 0.45 \\
\hline \multirow[t]{4}{*}{ Bank Loan Loss Provisions } & $I S S^{E D F}$ & & & & $\begin{array}{r}-13.594 \\
{[-4.30]}\end{array}$ & & $\begin{array}{r}-13.913 \\
{[-4.42]}\end{array}$ \\
\hline & LoanLosses & $\begin{array}{l}-0.397 \\
{[-1.72]}\end{array}$ & $\begin{array}{l}-0.139 \\
{[-0.59]}\end{array}$ & $\begin{array}{c}10.182 \\
{[2.00]}\end{array}$ & $\begin{array}{r}4.783 \\
{[1.34]}\end{array}$ & $\begin{array}{r}1.777 \\
{[0.36]}\end{array}$ & $\begin{array}{l}-0.161 \\
{[-0.05]}\end{array}$ \\
\hline & Controls & No & Yes & No & No & Yes & Yes \\
\hline & $R^{2}$ & 0.14 & 0.41 & 0.10 & 0.28 & 0.32 & 0.45 \\
\hline
\end{tabular}
on Newey-West (1987) standard errors allowing for serial correlation up to 2 lags. 
Table 8

\section{Determinants of Issuer Quality}

Time-series regressions of issuer quality $I S S^{E D F}$ on levels and past changes of interest rates:

$$
I S S_{t}^{E D F}=a+b \cdot y_{S, t}^{G}+c \cdot\left(y_{L, t}^{G}-y_{S, t}^{G}\right)+d \cdot r x_{t-1}^{H Y}+e \cdot D E F_{t}^{H Y}+u_{t} \text {, or } \Delta_{k} I S S_{t}^{E D F}=a+b \cdot \Delta_{k} y_{S, t}^{G}+c \cdot \Delta_{k}\left(y_{L, t}^{G}-y_{S, t}^{G}\right)+d \cdot r x_{t-k-1 \rightarrow t-1}^{H Y}+e \cdot \Delta_{k} D E F_{t}^{H Y}+\Delta_{k} u_{t} \cdot
$$

$y_{S}{ }^{G}$ denotes the short-term Treasury bill yield; $y_{L}{ }^{G}-y_{S}{ }^{G}$ denotes the term spread, $D E F^{H Y}$ is the issuer-weighted high yield default rate from Moody's, $r_{L}{ }^{H Y}-r_{L}{ }^{G}$ is the excess high yield return, and $\Delta_{k}$ denotes the $k$-year difference. In columns (1) to (5) we regress the level of $I S S^{E D F}$ on a number of covariates, columns (6) to (10) repeat this analysis in first differences, and columns (11) to (15) in second differences. In the last two columns in each block we add additional controls for lagged stock market returns and macroeconomic variables (the growth in industrial product, real consumption growth, and a recession indicator). Robust $t$-statistics are shown in brackets.

\begin{tabular}{|c|c|c|c|c|c|c|c|c|c|c|c|c|c|c|c|c|}
\hline \multirow{6}{*}{ Levels: } & \multirow{4}{*}{$\begin{array}{l}y_{S, t}^{G} \\
\left(y_{L, t}^{G}-y_{S, t}^{G}\right)\end{array}$} & \multicolumn{5}{|c|}{$I S S^{E D F}$} & \multicolumn{5}{|c|}{$\Delta_{1} I S S^{E D F}$} & \multicolumn{5}{|c|}{$\Delta_{2} I S S^{E D F}$} \\
\hline & & \multirow{2}{*}{$\begin{array}{r}(1) \\
-0.047 \\
{[-1.63]}\end{array}$} & \multirow[t]{2}{*}{ (2) } & \multirow{2}{*}{$\begin{array}{r}(3) \\
-0.036 \\
{[-1.22]}\end{array}$} & \multirow{2}{*}{$\begin{array}{r}(4) \\
-0.035 \\
{[-1.14]}\end{array}$} & \multirow{2}{*}{$\begin{array}{r}(5) \\
-0.026 \\
{[-0.99]}\end{array}$} & \multirow[t]{2}{*}{ (6) } & \multirow[t]{2}{*}{ (7) } & \multirow[t]{2}{*}{ (8) } & \multirow[t]{2}{*}{ (9) } & \multirow[t]{2}{*}{$(10)$} & \multirow[t]{2}{*}{ (11) } & \multirow[t]{2}{*}{ (12) } & \multirow[t]{2}{*}{ (13) } & \multirow[t]{2}{*}{ (14) } & \multirow[t]{2}{*}{ (15) } \\
\hline & & & & & & & & & & & & & & & & \\
\hline & & $\begin{array}{r}-0.277 \\
{[-4.91]}\end{array}$ & & $\begin{array}{r}-0.233 \\
{[-3.41]}\end{array}$ & $\begin{array}{r}-0.218 \\
{[-2.98]}\end{array}$ & $\begin{array}{r}-0.204 \\
{[-2.61]}\end{array}$ & & & & & & & & & & \\
\hline & $r x_{t-1}^{H Y}$ & & $\begin{array}{r}0.014 \\
{[1.57]}\end{array}$ & $\begin{array}{r}0.015 \\
{[2.78]}\end{array}$ & $\begin{array}{r}0.009 \\
{[1.42]}\end{array}$ & $\begin{array}{r}0.016 \\
{[3.14]}\end{array}$ & & & & & & & & & & \\
\hline & $D E F_{t}$ & & $\begin{array}{l}-0.076 \\
{[-3.11]}\end{array}$ & $\begin{array}{l}-0.013 \\
{[-0.59]}\end{array}$ & $\begin{array}{l}-0.017 \\
{[-0.68]}\end{array}$ & $\begin{array}{l}-0.010 \\
{[-0.40]}\end{array}$ & & & & & & & & & & \\
\hline \multirow[t]{4}{*}{$\begin{array}{l}\text { 1-year } \\
\text { Changes: }\end{array}$} & $\Delta_{1} y_{S, t}^{G}$ & & & & & & $\begin{array}{l}-0.107 \\
{[-2.41]}\end{array}$ & & $\begin{array}{c}-0.072 \\
{[-1.65]}\end{array}$ & $\begin{array}{r}-0.073 \\
{[-2.04]}\end{array}$ & $\begin{array}{r}-0.078 \\
{[-2.58]}\end{array}$ & & & & & \\
\hline & $\Delta_{1}\left(y_{L, t}^{G}-y_{S, t}^{G}\right)$ & & & & & & $\begin{array}{r}-0.335 \\
{[-5.99]}\end{array}$ & & $\begin{array}{r}-0.173 \\
{[-2.74]}\end{array}$ & $\begin{array}{l}-0.165 \\
{[-2.71]}\end{array}$ & $\begin{array}{r}-0.137 \\
{[-2.05]}\end{array}$ & & & & & \\
\hline & $r x_{t-1}^{H Y}$ & & & & & & & $\begin{array}{r}0.031 \\
{[6.60]}\end{array}$ & $\begin{array}{r}0.025 \\
{[5.00]}\end{array}$ & $\begin{array}{r}0.014 \\
{[2.24]}\end{array}$ & $\begin{array}{r}0.018 \\
{[3.25]}\end{array}$ & & & & & \\
\hline & $\Delta_{1} D E F_{t}$ & & & & & & & $\begin{array}{l}-0.043 \\
{[-1.74]}\end{array}$ & $\begin{array}{l}-0.025 \\
{[-1.11]}\end{array}$ & $\begin{array}{r}-0.031 \\
{[-1.36]}\end{array}$ & $\begin{array}{r}-0.020 \\
{[-1.11]}\end{array}$ & & & & & \\
\hline \multirow[t]{6}{*}{$\begin{array}{l}\text { 2-year } \\
\text { Changes: }\end{array}$} & $\Delta_{2} y_{S, t}^{G}$ & & & & & & & & & & & $\begin{array}{l}-0.134 \\
{[-3.31]}\end{array}$ & & $\begin{array}{r}-0.062 \\
{[-1.94]}\end{array}$ & $\begin{array}{l}-0.061 \\
{[-1.70]}\end{array}$ & $\begin{array}{r}-0.084 \\
{[-1.92]}\end{array}$ \\
\hline & $\Delta_{2}\left(y_{L, t}^{G}-y_{S, t}^{G}\right)$ & & & & & & & & & & & $\begin{array}{r}-0.410 \\
{[-7.63]}\end{array}$ & & $\begin{array}{l}-0.164 \\
{[-2.52]}\end{array}$ & $\begin{array}{l}-0.154 \\
{[-2.11]}\end{array}$ & $\begin{array}{l}-0.168 \\
{[-1.53]}\end{array}$ \\
\hline & $r x_{t-3 \rightarrow t-1}^{H Y}$ & & & & & & & & & & & & $\begin{array}{r}0.036 \\
{[6.91]}\end{array}$ & $\begin{array}{r}0.027 \\
{[4.47]}\end{array}$ & $\begin{array}{r}0.019 \\
{[2.17]}\end{array}$ & $\begin{array}{r}0.018 \\
{[2.65]}\end{array}$ \\
\hline & $\Delta_{2} D E F_{t}$ & & & & & & & & & & & & $\begin{array}{r}-0.065 \\
{[-3.77]}\end{array}$ & $\begin{array}{r}-0.049 \\
{[-2.72]}\end{array}$ & $\begin{array}{r}-0.064 \\
{[-2.78]}\end{array}$ & $\begin{array}{r}-0.083 \\
{[-2.45]}\end{array}$ \\
\hline & Other controls & None & None & None & $\begin{array}{c}\text { Lagged } \\
M K T\end{array}$ & $\begin{array}{l}\text { Macro } \\
\text { Vars }\end{array}$ & None & None & None & $\begin{array}{c}\text { Lagged } \\
M K T\end{array}$ & $\begin{array}{l}\text { Macro } \\
\text { Vars }\end{array}$ & None & None & None & $\begin{array}{l}\text { Lagged } \\
M K T\end{array}$ & $\begin{array}{c}\text { Macro } \\
\text { Vars }\end{array}$ \\
\hline & $R^{2}$ & 0.44 & 0.34 & 0.53 & 0.55 & 0.61 & 0.36 & 0.49 & 0.55 & 0.62 & 0.74 & 0.47 & 0.59 & 0.62 & 0.64 & 0.75 \\
\hline
\end{tabular}

